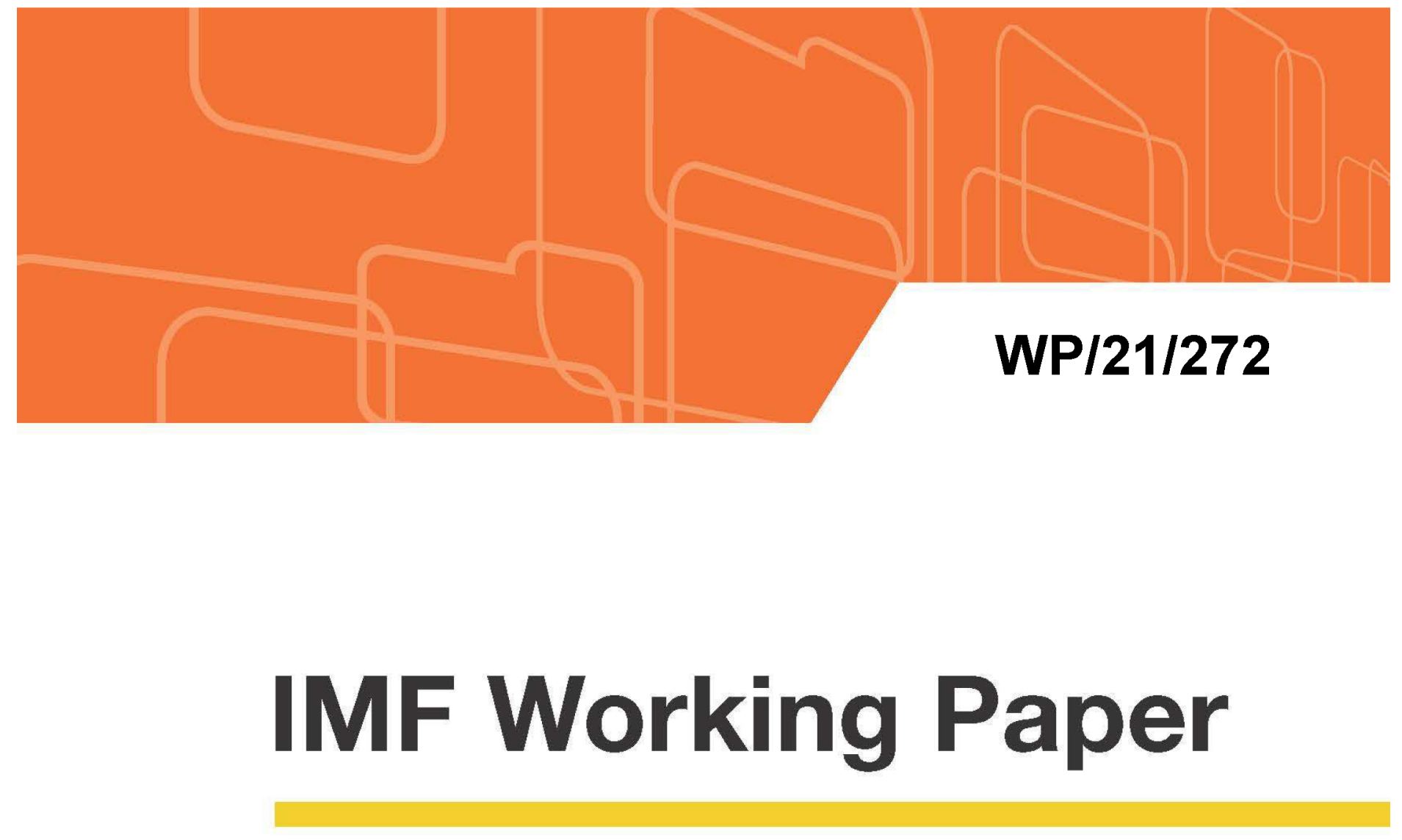

\title{
Uncertainty and Public Investment Multipliers: The Role of Economic Confidence
}

\author{
by William Gbohoui
}

IMF Working Papers describe research in progress by the author(s) and are published to elicit comments and to encourage debate. The views expressed in IMF Working Papers are those of the author(s) and do not necessarily represent the views of the IMF, its Executive Board, or IMF management. 


\title{
IMF Working Paper
}

Fiscal Affairs Department

\section{Uncertainty and Public Investment Multipliers: The Role of Economic Confidence}

\author{
Prepared by William Gbohoui ${ }^{1}$
}

Authorized for distribution by Paulo Medas

November 2021

\section{IMF Working Papers describe research in progress by the author(s) and are published to elicit comments and to encourage debate. The views expressed in IMF Working Papers are those of the author(s) and do not necessarily represent the views of the IMF, its Executive Board, or IMF management.}

\begin{abstract}
This paper investigates how macroeconomic uncertainty affects the fiscal multiplier of public investment. In theory, uncertainty can reduce the multiplier if the private sector becomes more cautious and does not respond to the fiscal stimulus. Conversely, it can increase the fiscal multiplier if public investment shocks improve private agents' expectations about future economic outlook, and lead to larger private spending. Using the disagreement about GDP forecasts as a proxy for uncertainty, we find that unexpected increases in public investment have larger and longer-lasting effects on output, investment, and employment during periods of high uncertainty, with multipliers above 2 , and the larger multipliers are not driven by economic slack. Public investment shocks are also found to boost private sector confidence during heightened uncertainty, driving-up expectations about future economic development which in turn magnify private sector response to the initial stimulus.
\end{abstract}

JEL Classification Numbers: E22; E62; E32; C33; D80.

Keywords: Public investment; private investment; fiscal multipliers; corporate balance sheet. Author's E-Mail Address: WGbohoui@imf.org

\footnotetext{
${ }^{1}$ The author would like to thank, Paolo Mauro, Catherine Pattillo, Paulo Medas, Raphael Espinoza, Bas Bakker, Philip Barrett, Adil Mohommad, Cedric Okou, and IMF's Fall 2020 Fiscal Monitor Workshop attendants for many helpful comments, Yuan Xiang and Juliana Gamboa for research assistance, and Meron Haile and Joni Mayfield for editorial assistance.
} 


\section{TABLE OF CONTENTS}

ABSTRACT _ 2

I. INTRODUCTION _

II. SELECTED LITERATURE REVIEW ___ $\underline{6}$

III. EMPIRICAL STRATEGY _ 2

IV. ECONOMETRIC RESULTS __ 12

V. ROBUSTNESS EXERCISE __ 20

VI. CONCLUSION _ 21

REFERENCES — 22

ANNEX — 29

FIGURES

Figure 1. Macroeconomic Effects of Public InVestment Shocks

Figure 2. EfFects of Public InVestment Shocks on Mean and Standard Deviation of GDP FORECASTS

Figure 3. DyNAMICS OF MACROECONOMIC UnCERTAINTY AND GDP GROWTH

Figure 4. EFFects of Public InVestment Shocks on OutPut Controlling for the STATE OF THE ECONOMY 


\section{INTRODUCTION}

Is fiscal policy more effective when macroeconomic uncertainty is high? This question is of significant importance for policymakers because during periods of economic turmoil such as the ongoing COVID-19 pandemic or the Global Financial Crisis, there is a concern that uncertainty could hold economic activity down, exacerbate economic scars, or delay the recovery. The theoretical literature suggests that higher uncertainty could slow down economic activity because businesses and consumers adopt a wait-and-see attitude (Bernanke (1983); Bloom (2009), Bachmann et al. (2013)), or there is an option value to waiting to invest that is extinguished when an investment is undertaken (Dixit and Pindyck (1994)). An implication from this literature is that a rise in uncertainty would reduce the effectiveness of economy policy because it makes firms and household more cautions in responding to price changes (Bloom et al. (2018)). This policy ineffectiveness amid elevated uncertainty is supported by recent empirical studies on monetary policy (Aastveit et al. (2017), Castelnuovo and Pellegrino (2017), Eickmeier et al. (2018), Pellegrino $(2018,2020))$. However, the effect of uncertainty on the transmission of fiscal policy shocks to the economy has been rarely studied in the empirical literature. Moreover, the few papers that addressed the questions are not conclusive. Some studies suggest that fiscal multipliers are larger when uncertainty is high (Arčabić and Cover (2016), Berg (2019)). But others find lower multiplier during heightened uncertainty (Alloza (2018)).

Against this backdrop, this paper addresses two specific issues. First, it assesses the extent to which uncertainty magnifies the macroeconomic impact of discretionary public investment increases. The analysis focuses on the multiplier of public investment because public investment stands apart as a powerful instrument to implement fiscal stimulus. As shown in the literature surveyed below, public investment has the potential to promote short-term growth, strengthen economic resilience and support long-term economic transformation. Public investment is also temporary by nature, can be delivered in a timely fashion, and could prioritize sectors (health, education, environment, digitalization, innovation) with large positive externalities for the rest of the economy. In addition, raising public investment could mitigate excess savings and foster longer-term productivity growth, especially if it crowds-in private investment.

Second, the paper explores the mechanism through which uncertainty affects the fiscal multiplier. There is a common belief among economists and policymakers that the confidence of households and firms are essential to the transmission of policy shocks (Farmer (2010)). For example, the prolonged low economic activity during the Great Recession was mostly attributed to the collapse of the consumer confidence. ${ }^{2}$ This belief is corroborated by the empirical research which finds that positive shocks to economic confidence generate positive and persistent output effects (Guimaraes et al. (2016), Barsky and Sims (2012), Carroll et al. (1994)). More generally, the economic theory also postulates that changes in expectations are an important driver of economic fluctuations (see Beaudry and Portier (2006); or Benhabib and Farmer (1999) for a review). Hence, the economic

\footnotetext{
${ }^{2}$ For example, Russel Roberts argued in January 2009: "But the economy is not stagnant because of a lack of spending. The economy is stagnant because of a lack of confidence in the future. Government spending on bridges, roads and new schools will stimulate the construction industry. But without confidence, the benefits will not spread to the rest of the economy."
} 
literature suggests that fiscal shocks could have larger (lower) output effects if they improve (weaken) private agents' expectations about future economic outlook. But there is little evidence on how public investment shocks affect economic confidence, especially during economic turmoil. ${ }^{3}$ In a pamphlet on the effectiveness of fiscal stimulus, Cochrane (2009) even argues: there is neither theory, nor evidence that fiscal stimulus will increase people confidence. This paper sheds further light on the latter by assessing how public investment shocks affect economic confidence and whether their effects vary with the degree of macroeconomic uncertainty.

Our empirical strategy focuses on the short-to-medium run effects of public investment shocks on output, private investment and employment using a dataset covering 72 countries over the period 1996-2019. The results indicate that public investment shocks have positive and long-lasting effects on output, private investment, and employment. To assess how uncertainty affects public investment multipliers, we use the standard deviation of GDP forecasts across professional forecasters as measure of uncertainty (Altig et al. (2020)). The findings reveal that public investment multipliers are larger during periods of high uncertainty. For instance, during periods of heightened uncertainty, output increases by 2.7 percent, private investment by 10.1 percent, and employment by 1.2 percent over a two-year period in response to a 1 percentage point of GDP increase in public investment. These effects are significantly larger compared to those obtained in a linear model ( 0.6 percent increase in output), or in periods of low uncertainty where the null hypothesis of no effects cannot be rejected. These results can be reconciled with the theoretical predictions that uncertainty depresses business investment by considering that during high uncertainty, private spending starts from a lower level. Hence, public investment boosts the activity of households and firms, that would otherwise postpone their consumption and investment spending, by more compared to normal times leading to larger multipliers.

The paper also finds that discretionary increases of public investment improve economic confidence, proxied by the change in the mean (and the dispersion) of growth forecasts. The results show that under high uncertainty, increases in public investment significantly buttress private sector confidence. These findings suggest that in face of acute uncertainty, a well-crafted, wellcommunicated, and well-implemented public investment strategy signals government commitment to stabilize the economy and to promote growth. Public investment shocks boost private sector confidence likely because they drive-up expectations of future productivity growth (Bachmann and Sims (2012)). Higher expectations about future economic development in turn generate stronger private response to the initial fiscal stimulus. In fact, as postulated by the literature on the accelerator model of investment dynamics, private sector's expectations about future growth are a key determinant of its current investment decisions (Jorgenson (1963), Jorgenson and Siebert (1968), Hall (1977)). Conversely, the results show that public investment shocks weaken confidence when implemented in periods of low uncertainty, likely because they reinforce some investors' pessimistic expectations about near-term economic outlook.

A further step is taken to investigate whether the larger multipliers obtained during periods of high uncertainty reflect the high multipliers measured during recessions (Auerbach and Gorodnichenko

\footnotetext{
${ }^{3}$ To our knowledge, Bachmann and Sims (2012), Alesina et al. (2015), and Berg (2019) are the rare exceptions.
} 
(2012, 2013b), and thus that our finding is driven by the correlation between high uncertainty and low growth. To do so, the effect of uncertainty on public investment multipliers is allowed to vary with the state of the economy. The results indicate that during periods of high uncertainty, public investment shocks have a positive and statistically significant effect on output irrespective to the state of the economy. However, the null hypothesis of no effect cannot be rejected when uncertainty is low regardless of whether the economy is in a high or low growth state. These findings suggest that the degree of uncertainty matters for the size of public investment multipliers, even after controlling for the business cycle.

The contribution of this paper is threefold. First, it extends the literature on the state-dependency of fiscal multipliers to account for the degree of macroeconomic uncertainty. Second, by focusing on positive investment shocks, it helps disentangle the multipliers of stimulative government investment shocks from those driven by spending cuts in periods of recession. This differentiation is important because it is not always the case that public investment is going up in recessions (i.e., acting countercyclically) and the economy does not respond symmetrically to government spending increases or decreases. Third, to the best of our knowledge, this is the first empirical paper that studies how macroeconomic uncertainty impacts the effects of public investment on economic confidence in a large sample of countries. Previous attempt is limited to Berg (2019) for Germany.

The remainder of the paper is organized as follows. Section II briefly discusses the literature. Section III lays out the empirical strategy which results are discussed in section IV. Section V is devoted to a set of robustness exercises and section VI concludes.

\section{Selected Literature ReVieW}

\section{A. Traditional Determinants of Fiscal multipliers: The Case for Public Investment}

Although the origin of the notion of multiplier can be dated back to Francois Quesnay (1758)'s Tableau Economique, ${ }^{4}$ the modern theory of multipliers derives from Keynes' idea that an exogenous increase in government expenditure generates several rounds of income effects, resulting in a multiplying effect on aggregate output. Hence, fiscal multipliers are defined as the ratio of a change in output to an exogenous and temporary change in the fiscal deficit with respect to their respective baselines (Spilimbergo et al. (2009)). The literature on multipliers has been revived since the onset of the global financial crisis, as many governments in advanced economies first implemented large fiscal stimuli, and later switched to fiscal consolidation. But results remain inconclusive, suggesting that fiscal multipliers are country-, time-, and circumstance-specific (see Aschauer (1989), Romer and Romer (2010), Auerbach et al. (2010), Auerbach and Gorodnichenko (2013a), Mineshima et al. (2014); Batini et al. (2014); or Ramey (2019) for a comprehensive survey of the post-GFC literature).

\footnotetext{
${ }^{4}$ Francois Quesnay (1758)'s Tableau Economique (Economic Table) is the first formal formulation of interdependent systems in economics that shows variables in one period (time $t$ ) feeding into variables in the next period (time $t+1$ ), and a constant rate of flow yielding geometric series, which computes a multiplier. The Tableau which laid the foundation of the Physiocrat school of economics is credited as the origin of multiplier theory (Spiegel (1991)).
} 
The effects of fiscal shocks depend on the structural characteristics of the economy, as well as the point in the business cycle. Multipliers vary with the degree of trade openness (Barrell et al. (2012), Ilzetzki et al. (2013)) and financial market development (Spilimbergo et al. (2009), Koh (2017)), the exchange rate regime (Born et al. (2013)), or the size of automatic stabilizers (Dolls et al. (2012)). Fiscal multipliers are also found to be larger in countries with better governance and more efficient fiscal institutions (Abiad et al. (2016), Miyamoto et al. (2020)). Moreover, multipliers could be larger in periods of recession than in periods of expansion potentially because capacity constraints are lessened during downturns, reducing the risk of private sector crowd-out. Fiscal multipliers also depend on monetary policy reaction and whether interest rates are near the zerolower bound. But the empirical evidence on higher multipliers during recessions and under various monetary policy stances has been mixed, reflecting differences in sample, identification, and estimation approaches. ${ }^{5}$ In addition, the effects of fiscal shocks are found to vary with the ex-ante strength of fiscal positions as sustainability concerns could weaken private sector response (Ilzetzki et al. (2013), Nickel and Tudyka (2014), Huidron et al. (2019)).

The design of fiscal shocks also matters for its effectiveness. In theory, the Ricardian equivalence theorem, revisited by Barro (1974), predicts that temporary changes in fiscal policy have no real effects if individuals live forever, are rational and farsighted, and capital markets are perfect. But a fiscal stimulus could have larger effects if it is targeted to liquidity constrained consumers or businesses (Heathcote (2005), Gbohoui (2018)) because they temporarily lessen financing constraints. The effects of a fiscal stimulus also depend on how it is financed (Mountford and Uhlig (2009)) and the direction of the shocks: contractionary versus expansionary (Barnichon et al. (2021), Riera-Crichton et al. (2015)). Moreover, the size of fiscal multipliers varies by fiscal instruments, depending on the composition of fiscal packages (See Alesina and Ardagna (2010), or Cournède et al. (2013), or Johansson (2016) for a literature review). A meta-analysis of the literature points to average estimates for public spending multipliers that are higher than tax multipliers, with public investment multipliers larger than that of consumption (Ilzetzki et al. (2013), Abiad et al. (2016), Gechert (2015), Gechert and Rannenberg (2018)).

Public investment multipliers could be larger because public investment has multiple effects on the economy. Economic theory suggests that during the construction phase, an increase in public investment boosts aggregate demand through the short-term Keynesian multiplier, with the expansion of consumption (via higher workers' income) as well as of other expenditures. Evidence in the aftermath of the GFC includes Azam et al. (2012) on Latvia; CBO (2015) for the US; or Zimmermann (2020) for India. A second effect occurs as capital expenditure turns into effective capital formation, increasing the productive capacity and hence the growth potential of the economy (Fournier (2016), Petrović et al. (2021)). These supply-side effects depend on the effectiveness of public administration, especially the efficiency of public investment management institutions and absorptive capacity (IMF (2014), Abiad et al. (2016), Presbitero (2016), Miyamoto

\footnotetext{
${ }^{5}$ Papers that study the questions include Baum et al. (2012), Auerbach and Gorodnichenko (2012, 2013b), Blanchard and Leigh (2013), Fatás and Summers (2018), Gechert and Rannenberg (2018), and Ramey et al. (2018) for state-dependent multipliers, and Cogan et al. (2010); Christiano et al. (2011); Ramey (2011), Coenen et al. (2012), Crafts and Mills (2013), and Miyamoto et al. (2018) for the importance of the stance of monetary policy.
} 
et al. (2020), Gurara et al. (2020)). Third, public investment has also the potential to further boost long-term growth if it generates positive externalities to other sectors (Arrow (1962), Romer (1986)), fosters innovation (Moretti et al. (2019), Agenor et al. (2015)) or crowds-in private investment especially if newly installed public capital is complementarity to private capital (Aschauer (1989)). The recent literature finds that increases in public investment raise output, both in the short-term and in the long-term, crowds-in private investment, and reduces unemployment (IMF (2020a, 2014); Miyamoto et al. (2020); Abiad et al. (2016)).

\section{B. Fiscal Multipliers and Uncertainty: The Role of Confidence in the Transmission of Public Investment Shocks}

A growing strand of the literature suggests that uncertainty has a negative effect on economic activity (See Bloom (2014) for a literature review). Most of the theoretical predictions in this literature are based on the idea that non-smooth adjustment frictions and investment irreversibility lead firms to pause hiring and investment when facing a more uncertain environment, dampening economic activity (Bloom et al. (2018), Bachman et al. (2013), Bloom (2009), Bernanke (1983)). Bloom et al. (2007) and Baum et al. (2008) report a negative relationship between firm-level investment and the volatility of stock returns for US and UK firms respectively. Using micro data from the Federal Reserve Bank of Philadelphia's Business Outlook Survey and Germany's IFO Business Climate Index, Bachman et al. (2013) find that increases in business uncertainty are associated with prolonged declines in economic activity, arguing that increases in business uncertainty weaken business confidence. More recently, Baker et al. (2020) use real-time forwardlooking uncertainty measures to show that about half of the forecasted output contraction in yearon-year US real GDP is driven by COVID-related uncertainty. In a DSGE model, Bloom et al. (2018) show that not only does uncertainty reduce firm-level investment (see also Guiso and Parigi (1999), Kang et al. (2014)), uncertainty could make government policy, like wage subsidies, temporarily less effective because firms become more cautious in responding to price changes.

However, little is known about whether and how the level of economic uncertainty affects the effectiveness of fiscal policy. In addition, the few papers that have studied the subject to date are not conclusive. Alloza (2018) used a structural VAR to assess how uncertainty affects the effectiveness of fiscal policy in the United States. Using the (implied) stock market volatility to proxy uncertainty, the paper concludes that output decreases (increases) in response to positive defense spending shocks during period of high (low) uncertainty. In a similar framework, Arčabić and Cover (2016) reach opposite results, and conclude that government spending shocks have a larger impact on GDP in high uncertainty regimes than under regimes with either medium or low uncertainty. They argue that during periods of high uncertainty, government spending crowds-in private sector investment spending while the opposite happens during periods of low uncertainty. Using the Ifo Business Climate Survey (Ifo-BCS) to construct business uncertainty index, Berg (2019) reports larger effects for government spending shocks during high uncertainty for Germany. More specifically, it finds that government spending multipliers are negative during low uncertainty, while they are positive (above 2) when uncertainty levels are high, leading to a persistent rise in overall economic activity. 
A key insight by Berg (2019) is that business confidence is a potential transmission channel for the positive correlation between fiscal policy effectiveness and business uncertainty. The author shows that after an expansionary spending shock, business confidence declines when uncertainty is low whereas firms become much more optimistic regarding their prospective production activities if a fiscal stimulus is announced in times of high uncertainty. Several papers have highlighted the importance of confidence in driving economic fluctuations. Focusing on consumption, Carroll et al. (1994) established that consumer confidence causes, in the sense of Granger (1969), consumption and income one year-ahead. More recently, Barsky and Sims (2012) have shown that positive shocks to consumer confidence have a positive and persistent effect on consumption and output in the long run, suggesting that consumer confidence is a good indicator for agents' beliefs about future output. Alesina et al. (2015) argue that expenditure-based and taxbased fiscal consolidation plans entail different output losses because they have differentiated effect on consumer and business confidence. Using a non-linear VAR model with a forwardlooking consumer confidence index from the Michigan Survey of Consumers over the period 1960-2011, Bachmann and Sims (2012) find that government spending multipliers are larger than 2 during recessions because they increase consumer confidence. They show that the effects of positive government spending shocks can be broken in two components: a direct effect due to the contemporaneous effect of spending on aggregate demand, and an indirect component where fiscal policy affects confidence which in turn influences output.

\section{EMPIRICAL STRATEGY}

\section{A. Measuring Macroeconomic Uncertainty}

Metrics proposed as proxies for uncertainty in the literature can be divided between backwardand forward-looking indicators. Backward-looking measures, like those derived from statistical models fit to standard macroeconomic data, are less appropriate to measure real-time uncertainty because the data that are the key inputs to the forecasting models are observable with delays. Existing forward-looking measures capture different dimensions of uncertainty and include stock market volatility (Bloom (2009)), Google News-based indexes of economic uncertainty and economic policy uncertainty indexes based on newspaper coverage frequency (Baker et al. (2016)), as well as the subjective uncertainty about future business growth (Altig et al. (2020)) and the disagreement among professional forecasters about the future dynamic of economic variables (Bachmann et al. (2013)).

In this paper macroeconomic uncertainty is measured by the standard deviation of GDP growth forecasts across professional forecasters as published by Consensus Economics, using the spring (April) vintage for each year. Several reasons underpin this choice. First, high levels of disagreement between professional forecasters about a basic variable like GDP growth are reasonable proxies for economic uncertainty. In fact, changes in professional forecasts have been found to predict subsequent changes in expectations in the broader population (Carroll (2003)). ${ }^{6}$ Moreover, the use of the disagreement between professional forecasters as a valid proxy for

\footnotetext{
${ }^{6}$ Compared to news-based measures of uncertainty, professional forecasters' expectations are also likely to be better reflections
} of economic uncertainty than that expressed by journalists. 
macroeconomic uncertainty is well established in the literature (Altig et al. (2020), Popescu and Smets (2010), Giordano and Söderlind (2003), Bomberger (1996)). ${ }^{7}$ Second, by focusing on GDP forecasts, the most basic economic aggregate, the analysis is capturing the uncertainty surrounding the broader macroeconomic outlook rather than uncertainty on "Wall Street" reflected in stock market volatility indexes. For example, Altig et al. (2020) has shown that the difference between the time paths of implied volatility indexes and broader measures of uncertainty at the onset of the COVID-19 pandemic reflects the difference between Wall Street and Main Street uncertainties. In fact, the former rose rapidly from late February 2020, peaked in mid-March, and fell back by late March as stock prices began to recover. But the latter peaked later when unemployment skyrocketed and then plateaued. Finally, the Consensus Forecast dataset allows for broad country coverage.

\section{B. Identifying Public Investment Shocks}

One important methodological challenge faced by researchers when assessing the effect of public investment on growth is endogeneity. In fact, countries that record high growth are relatively more likely to engage in large infrastructure projects. Conversely, a big push to public investment could foster short-and- long term growth. To establish the casual effects of public investment, this paper identifies exogenous investment shocks as forecast errors of public investment spending in percent of GDP. This identification approach pioneered by Auerbach and Gorodnichenko (2012) has been widely used in the recent literature on fiscal multipliers (see IMF (2014); Ramey and Zubairy (2018), Miyamoto et al. (2020)). The methodology aligns the information sets of the economic agents and the econometricians, thus overcoming the fiscal foresight problem that could stem from situations where economic agents anticipate changes in fiscal spending in advance and alter their investment and consumption behavior before the changes materialize. In such cases, relying on the change in public investment could lead to inconsistent estimates of the effects of public investment as the econometrician will be using a smaller set of information compared to economic agents. ${ }^{8}$

Our empirical strategy also controls for the potentially endogenous response of public investment to the state of the economy by using the same-year October forecasts in the computation of investment shocks. In fact, upward adjustments to public investment projects within the year due to information on economic performance (unexpectedly weaker/stronger growth or revenue realization) available after the forecast cutoff date could raise endogeneity concerns even if investment shocks are unanticipated. But given the substantial lags in fiscal policy especially for capital spending implementation, it is highly unlikely that additional information available after October would lead to adjustments in investment projects before December of the same year (Perotti (2002)).

\footnotetext{
${ }^{7}$ Other papers that used the forecast disagreement as measure of uncertainty include Federer (1993), Zarnovitz and Lambros (1987), Bond and Cummins (2004); Fuss and Vermeulen (2008); Clements (2008); and more recently Baker et al. (2016). Rich and Tracy (2010) and Boero et al. (2008) have a more critical view about using disagreement as a proxy for uncertainty.

${ }^{8}$ For further details on the fiscal foresight problem, see Forni and Gambetti (2010), Leeper et al. (2012), Leeper et al. (2013), and Ben Zeev and Pappa (2014).
} 
The paper focuses on positive investment shocks because the objective is to explore how a public investment push affects the economy. By doing so, it disentangles the multipliers of stimulative government investment shocks from those driven by spending cuts in periods of recession. This differentiation is important for at least two reasons. First, it is not always the case that public investment is countercyclical, i.e., going up in recessions. Second, the literature has shown that the effects of fiscal shocks could be asymmetric with respect to the sign of the shocks, contractionary or expansionary (Barnichon et al. (2021)), suggesting that the economy may not respond symmetrically to increases or decreases in public investment. A possible explanation for this asymmetry is that the size of the fiscal multiplier varies with the marginal propensity to consume (Gali et al. 2007), which in turn depends on the sign of the change in income (Bunn et al. (2018)).

In this paper, investment shock is defined as follows:

$$
\Delta I_{i, t}=I_{i, t}-I_{i, t}^{E} \text {, and } \Delta I_{i, t}^{+}=\Delta I_{i, t} \text { if } \Delta I_{i, t}>0,
$$

where for country $i$ and year $t, I_{i, t}$ is the realized public investment spending as a share of GDP and $I_{i, t}^{E}$ is the forecasted public investment spending. Forecasts are taken mainly from the October publications of the IMF World Economic Outlook for the same year. ${ }^{9}$

\section{Baseline Specification}

The analysis starts by quantifying the macroeconomic effects of public investment on output, employment, and private investment using the following specification:

$$
y_{i, t+k}-y_{i, t-1}=\alpha_{i}^{k}+\gamma_{t}^{k}+\beta^{k} \Delta I_{i, t}^{+}+\theta^{k} M_{i, t}+\varepsilon_{i, t}^{k}, \quad k=0,1,2
$$

where $y$ is the log of the macroeconomic variable of interest (real GDP, employment, and private investment), $\alpha$ is the country fixed effect, $\gamma$ is the time fixed effect, $\Delta I^{+}$is the identified public investment shock, and $M$ is a set of control variables, including lagged GDP growth. Following Ramey and Zubairy (2018), we also include lagged investment shocks to control for potential serial correlation in the shock variable.

Impulse response functions are constructed using the local projections pioneered by Jordà (2005). Equation (1) is estimated for each $k=0,1,2$, where $k=0$ is the year of the public investment shock. The coefficient $\beta^{k}$ gives the response of $y$ at time $t+k$ to the shock at time $t$. One advantage of the local projection method put forward by Auerbach and Gorodnichenko (2013a) and Ramey and Zubairy (2018) is that it does not impose the dynamic restrictions embedded in VAR specifications. It is also appropriate to estimating nonlinearities in the dynamic response and is robust to misspecification (Jordà (2005)). The confidence intervals associated with the impulse response functions are obtained by the estimated (clustered robust) standard errors of the

\footnotetext{
${ }^{9}$ Due to data limitations, forecasts from the Fall issue of the Organisation for Economic Co-operation and Development Economic Outlook for advanced economies are used because there are no forecasts of public investment for these economies during 2004-08 in IMF World Economic Outlook publications. Miyamoto et al. (2020) follows a similar approach.
} 
coefficient $\beta^{k}$ to control for the potential serial correlation that could result from the successive leading of the dependent variable.

\section{ECONOMETRIC RESUlTS}

\section{A. Linear Public Investment Multipliers}

Equation 1 is estimated using an unbalanced panel of 72 countries over the period 1996-2019. The primary sources of data used are the IMF World Economic Outlook, the Organisation for Economic Co-operation and Development (OECD), and Consensus Economics. ${ }^{10}$

Figure 1, Panel A.1. shows that public investment shocks have statistically significant and longlasting effects on output. ${ }^{11}$ An unanticipated 1 percentage point of GDP increase in public investment contemporaneously increases the level of output by about 0.23 percent. The output response remains statistically significant until the third year, and more than doubles overtime peaking at 0.58 percent two years after the shock. This finding likely reflects both the Keynesian effects, and the expansion of the productive capacity of the economy as public investment augments the physical infrastructure stock. These estimates fall within the range, from around zero to as high as 2, reported by previous research summarized by IMF 2020b (see also Gechert and Rannenberg (2018) for a recent review of existing estimates). ${ }^{12}$

The results also indicate that public investment shocks crowd-in private investment in the shortto-medium term. While the positive private investment response is not statistically significant in the first year, Figure 1, Panel B.1. shows that a public investment shock of 1 percentage point of GDP crowds-in private investment by more than 3 percent over two years.

Surprisingly, a discretionary push to public investment is found to have no statistically significant effect on employment. Figure 1, Panel C.1. shows that the effects of public investment shocks on employment are increasing over time but remain statistically insignificant. The reason may be that on average, employment is not far from full capacity.

We also estimate Equation 1 separately for the group of advanced economies, and the group of emerging and developing countries. Our findings confirm that the multipliers and the elasticity of employment are larger in advanced economies, where investment efficiency is likely to be higher (Annex Tables 2, 3 and 4).

\footnotetext{
${ }^{10}$ Annex Table 1 presents the countries covered by the analysis, the time coverage, and the exercise where they appear.

${ }^{11}$ Detailed results are presented in Annex Tables 2, 3 and 4.

12 The literature on public investment multipliers is not conclusive regarding their size and differences in the size of the multipliers often reflect differences in sample size, and in model specification, identification, and estimation approaches.
} 


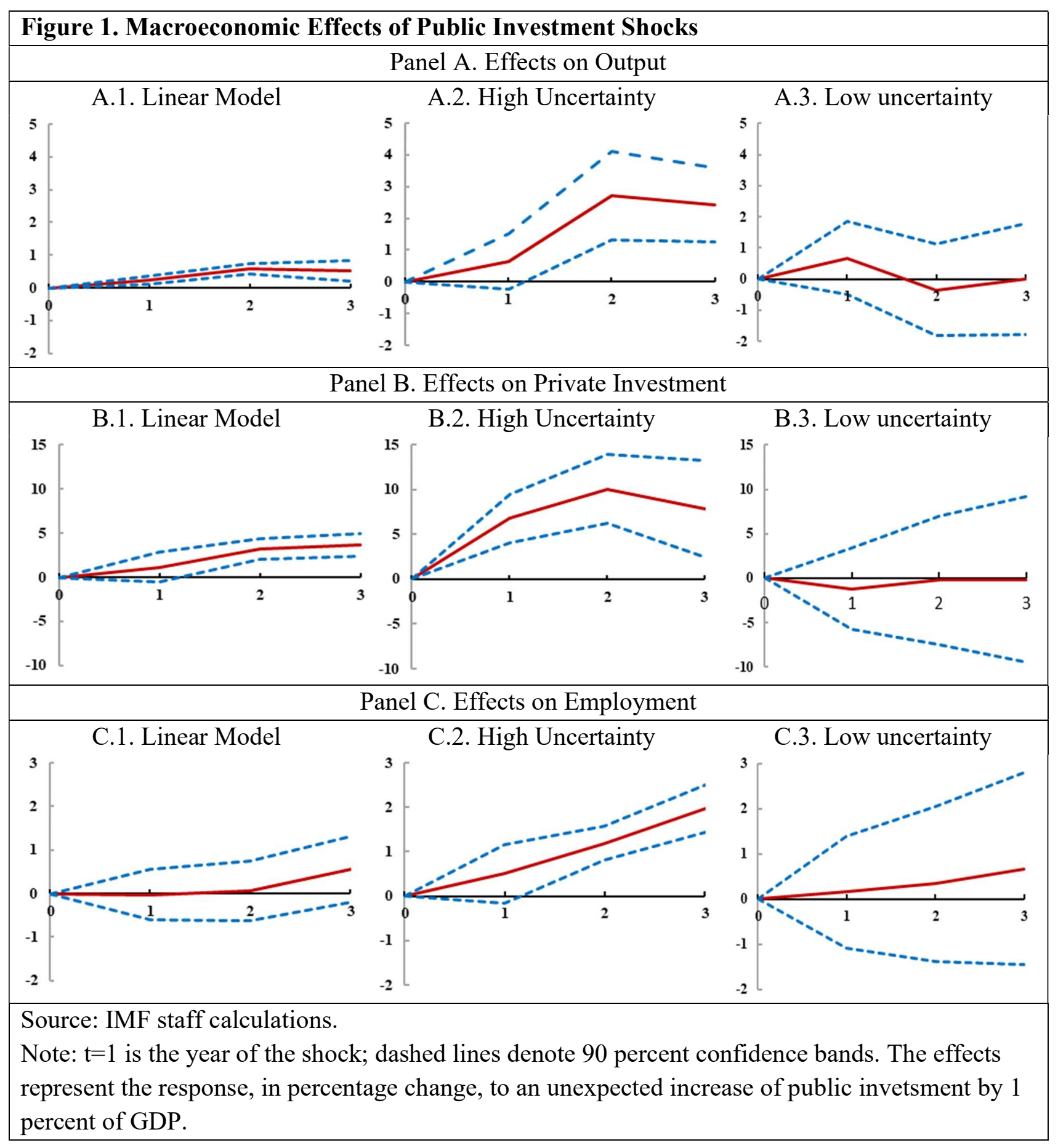

\section{B. Effects of Uncertainty on Public Investment Multipliers}

The analysis extends the literature on the state-dependency of fiscal multipliers to the degree of macroeconomic uncertainty. The sensitivity of public investment multipliers to the degree of macroeconomic uncertainty is assessed by using the following specification:

$$
y_{i, t+k}-y_{i, t-1}=\alpha_{i}^{k}+\gamma_{t}^{k}+\beta_{1}^{k} G\left(z_{i, t}\right) \Delta I_{i, t}^{+}+\beta_{2}^{k}\left(1-G\left(z_{i, t}\right)\right) \Delta I_{i, t}^{+}+\theta^{k} M_{i, t}+\varepsilon_{i, t}^{k}
$$


where $G\left(z_{i, t}\right)=\frac{\exp \left(-\delta z_{i t}\right)}{1+\exp \left(-\delta z_{i t}\right)}$ is the transition function between different levels of uncertainty in which $z$ is the measure of the degree of uncertainty normalized to have zero mean and unit variance; $\delta$, the curvature of the transition function, is set to 1 following the literature (Miyamoto et al. 2020, Abiad et al. (2016) $)^{13}$

The results reveal that public investment has larger effects on output, employment, and investment during periods of high uncertainty (Figure 2, Panel A.2.). ${ }^{14}$ The multiplier peaks at 2.7 over two years during periods of high uncertainty, versus 0.6 for the baseline estimate. Moreover, the multiplier remains statistically significant at the 99 percent threshold in the third year, suggesting that public investment has a longer-lasting effect on output when undertaken during periods of high uncertainty (See Annex Table 5). In periods of low uncertainty, the null hypothesis of no effects on output cannot be rejected, suggesting that positive estimates for multipliers are driven by periods of high uncertainty (Figure 2, Panel A.3.).

The crowding-in of private investment is also stronger in periods of high uncertainty. Figure 2, Panel B.2. shows that private investment increases by more than 10 percent over a period of 2 years after a 1 percentage point of GDP push to public investment implemented during high uncertainty. This response is more than twice larger compared to the private investment response in the linear model. During periods of low uncertainty, the null hypothesis of no public investment impact on private investment cannot be rejected (Figure 2, Panel B.3.).

Public investment shocks have also statistically significant and long-lasting effects on employment when economic uncertainty is high. Figure 2, Panel C.2. indicates that employment responds positively to public investment shocks implemented during periods of elevated uncertainty and the employment response increases as time passes. In contrast, the null hypothesis of no impact on employment cannot be rejected during periods of low uncertainty (Figure 2, Panel C.3.)

Overall, these results show that discretionary increases in public investment have larger effects in stimulating the economy and promoting long-term growth when implemented during periods of high uncertainty. These findings can be reconciled with the literature prescribing that uncertainty has a negative effect on economic activity (Bernanke (1983), Bloom et al. (2018)) by considering that private investment starts from a low level during periods of high uncertainty. Therefore, public investment lifts private investment by more compared to normal times, leading to larger multipliers. Our findings suggest that during periods of heightened uncertainty, increases in public investment might signal government commitment to aggregate stability and to promote growth. In fact, the larger private investment response suggests that during heightened uncertainty, public investment shocks could improve expectations about future economic developments. The

\footnotetext{
${ }^{13}$ Our results are robust to different values of $\delta$ (see Annex Table 11, Panel E). For the analysis of recession and expansion, Auerbach and Gorodnichenko (2013a) calibrated $\delta=1.5$ so that the economy spends about 20 percent of the time in recessionary regimes, consistently with the fraction of recessionary periods in the United States as measured by the NBER ( 21 percent). Miyamoto et al. (2020), Abiad et al. (2016), IMF (2014) set $\delta=1$ when assessing the effects of public investment efficiency, or the quality of governance.

${ }^{14}$ Detailed results are provided in Annex Table 5. The results are robust to alternative measure of investment shocks, different specification, and sample size (see the robustness section below).
} 
transmission channel of public investment shocks to the economy is further explored in the next section.

\section{Public Investment Shocks and Economic Confidence}

Confidence of households and firms is critical to the effectiveness of fiscal policy in stimulating the economy, as it determines the response of private sectors to fiscal shocks. Bachmann and Sims (2012) illustrated the mechanism by showing that public spending also has an indirect effect, where fiscal policy influences confidence that later influences output. This section studies the transmission channel of public investment shocks to the economy by assessing whether and how public investment affects economic confidence.

Economic confidence is proxied in this this paper by two indicators: the change in the mean and in the dispersion (standard deviation) of growth forecasts among professional forecasters. For instance, higher mean growth expectations are reasonable indication of an increase in the confidence of economic agents about future economic developments. In addition, the standard deviation among forecasters reflects the uncertainty surrounding the outlook. The rationale is that an increase in mean growth expectations combined with a reduction in the disagreement between forecasters about future growth developments reflects an improvement in confidence and higher certainty on the future of the economy. ${ }^{15}$

To test the validity of the confidence channel, the paper uses the specification below: ${ }^{16}$

$$
\Delta X_{i, t+k}=\alpha_{i}^{k}+\gamma_{t}^{k}+\beta^{k} \Delta I_{i, t}^{+}+\theta^{k} M_{i, t}+\varepsilon_{i, t}^{k}, \quad k=1,2,3 .
$$

where for country " $\mathrm{i}$ ", $\Delta X_{i, t+k}$ is the difference between the mean (standard deviation) of years " $\mathrm{t}$ " and " $\mathrm{t}+\mathrm{k}$ " growth forecasts in the spring vintage, $\alpha$ is the country fixed effect, $\gamma$ is the time fixed effect, and $M$ includes lagged GDP growth and the lag of the investment shock. ${ }^{17}$

The results are portrayed in Figure $2 .{ }^{18}$ They show that public investment shocks significantly increase the mean expectations of forecasters in the short term, but the effects turn statistically insignificant in the medium term (Figure 2, Panel A.1). Public investment shocks are also found to reduce uncertainty around forecasts of future growth. However, the effects are insignificant at all time horizons (Figure 2, Panel B.1).

\footnotetext{
${ }^{15}$ From a statistical point of view, assessing the effects of investment shocks on the dispersion of growth forecasts among forecasters also helps ensure that increases (decreases) in mean growth forecasts are not driven by over optimistic (pessimistic) expectation from a few forecasters, a well-known property of the mean.

${ }^{16}$ The intuition is that if public investment shocks lead systematically to a significantly higher growth forecasts and lower disagreement for the years ahead compared to the current year, it means that they improve confidence about future economic developments.

${ }^{17}$ For a given year $t(t+k)$, the forecast of the spring vintage of this year is considered.

${ }^{18}$ See detailed estimation results in Annex Table 6.
} 


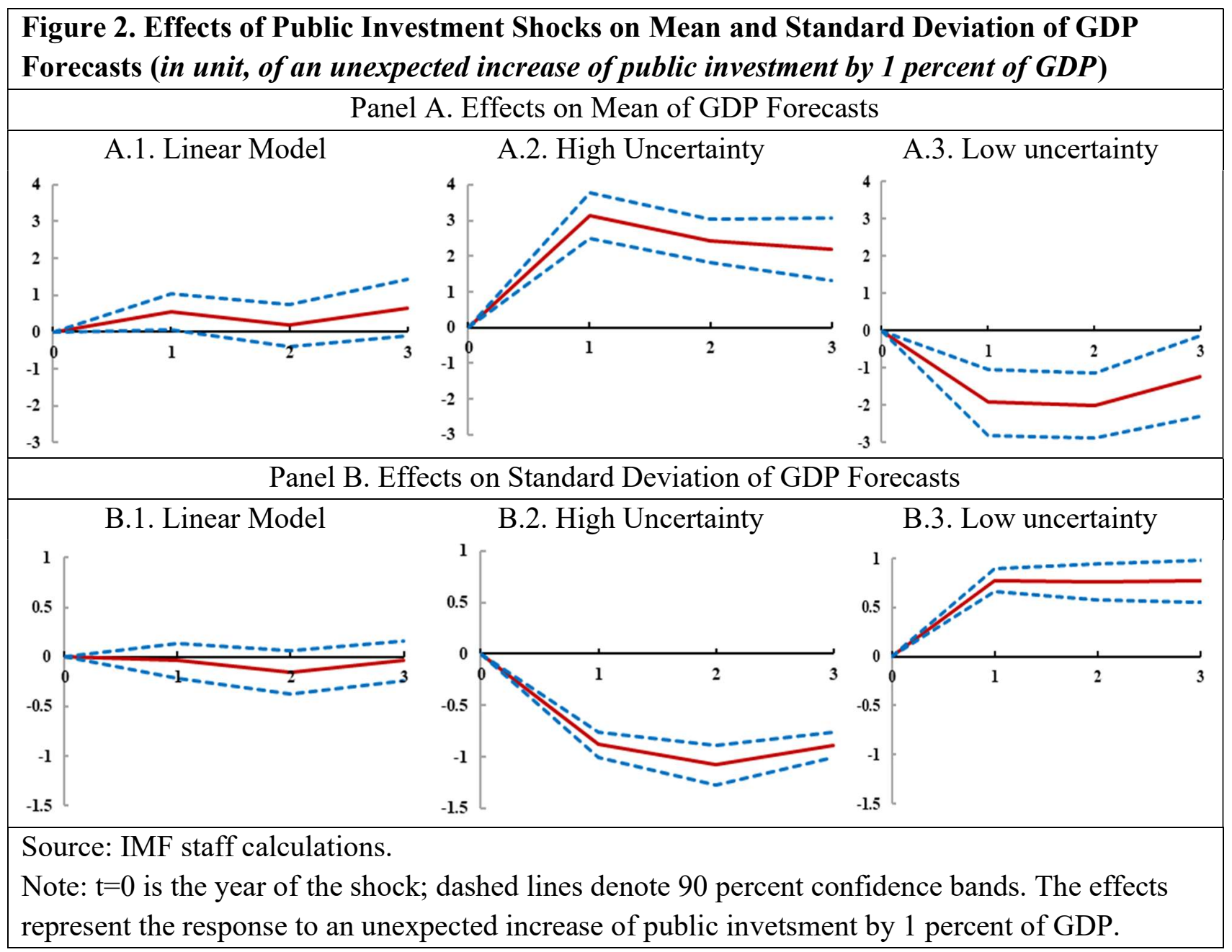

These insignificant effects could hide potential non-linearities in the effects of public investment on economic confidence. To further investigate the transmission channel of the effects of public investment on economic activity, the analysis assesses whether the effects of public investment on confidence depend on the degree of economic uncertainty, using the following specification:

$$
\Delta X_{i, t+k}=\alpha_{i}^{k}+\gamma_{t}^{k}+\beta_{1}^{k} G\left(z_{i, t}\right) \Delta I_{i, t}^{+}+\beta_{2}^{k}\left(1-G\left(z_{i, t}\right)\right) \Delta I_{i, t}^{+}+\theta^{k} M_{i, t}+\varepsilon_{i, t}^{k} .
$$

As in equation (3), $\Delta X$ is the change in the mean (standard deviation) of growth forecast at the spring vintage of Consensus Economics, $\alpha$ is the country fixed effect, $\gamma$ is the time fixed effect, and $M$ includes lagged GDP growth and the lag of the investment shock. Moreover, $G(\cdot)$ represents the transition function between different levels of uncertainty, and $z$ is the indicator of the degree of uncertainty normalized to have zero mean and unit variance as in equation (2).

The results indicate that public investment shocks have nonlinear effects on confidence depending on the degree of ex-ante economic uncertainty, and these effects are statistically significant. ${ }^{19}$ When implemented during periods of high uncertainty, public investment shocks increase the

\footnotetext{
${ }^{19}$ See detailed estimation results in Annex Table 7.
} 
growth expectations by economic agents and reduce forecasters' disagreement about short-andmedium-term growth paths (Figure 2, Panels A.2. and B.2). A plausible reason is that during heightened uncertainty, unexpected public investment shocks signal government's commitment to growth and stability, boosting private sector confidence. During periods of low uncertainty, unanticipated shocks to public investment lead to pessimistic expectations about future growth and a higher disagreement between forecasters, likely reflecting the volatility induced by unexpected shocks to public investment in normal times (Figure 2, Panels A.3 and B.3). For instance, even during normal times, some agents may be concerned that the economy could take a downturn in the near future. An unexpected public investment shock could then confirm these pessimistic views, leading to the erosion of private sector confidence.

Combined with the previous results, these findings suggest that during high uncertainty, public investment shocks boost economic confidence thereby leading to a positive and stronger private demand response. The larger crowding-in effects on private investment obtained during periods of high uncertainty confirm that by raising confidence, a public investment push fosters investment from businesses that might otherwise become very cautious and postpone their hiring and investment decisions. According to the literature, the positive relationship between confidence and the economy obtains likely because empirical measures of confidence are reflective of changes in future economic fundamentals, in particular productivity (Barsky and Sims (2012), Bachmann and Sims (2012)). Hence, the macroeconomic effects of public investment shocks can be decomposed into two components: a direct effect because the investment spending shock itself is a component of aggregate demand, and an indirect effect through which public investment impacts confidence which in turn spurs private sector response to the initial fiscal stimulus. The results extend to a panel of countries the findings by Bachmann and Sims (2012) for the US and berg (2019) for Germany that confidence is a potential transmission channel of fiscal policy to the economy.

\section{Public Investment Multipliers and Uncertainty: The Role of the State of the Economy}

This section assesses whether the larger multipliers obtained during periods of high uncertainty are driven by the state of the economy. It starts by tacking stock of the dynamics of uncertainty and economic activity.

\section{Uncertainty and the State of the Economy}

Figure 3 plots the evolution of the changes in the uncertainty index and the annual growth rate for selected economies (China, Germany, UK, USA) for the period 1994-2019. We consider uncertainty as "countercyclical" if rising uncertainty is accompanied with declining growth rates, or decreasing uncertainty is associated with increasing growth rates. The shaded areas portray periods where uncertainty is not countercyclical-i.e., periods when both the uncertainty index and the growth rate are rising; or periods when both are declining.

\section{Figure 3. Dynamics of Macroeconomic Uncertainty and GDP Growth}


China

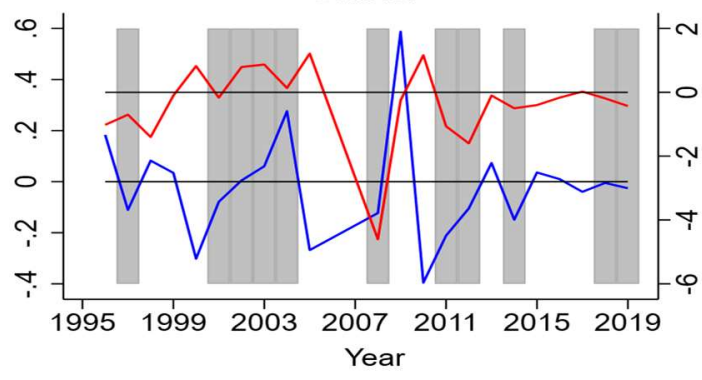

UK

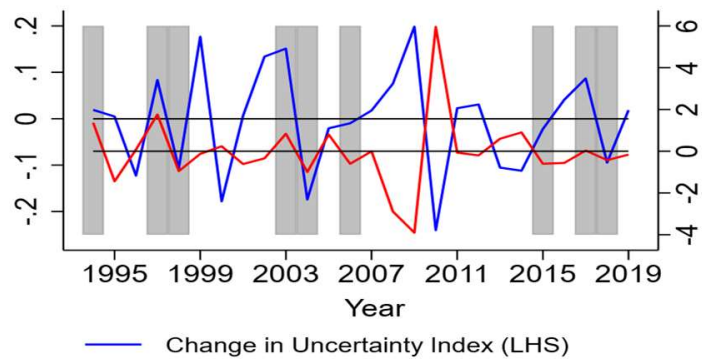

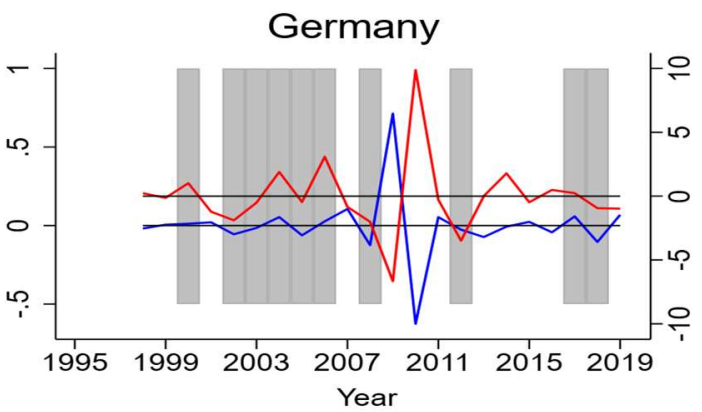

USA

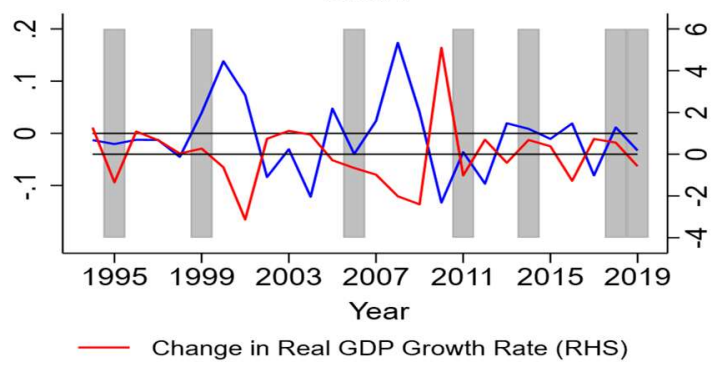

Source: Consensus Economics Forecasts, IMF WEO, and Authors' calculations.

Note: The figure shows the change in uncertainty (standard deviation of spring vintage of current year's GDP growth forecasts across professional forecasters by Consensus Economics) and the change in the real GDP growth rate.

The figure reveals that although uncertainty tends to be countercyclical, the uncertainty and the growth rate do not always move in opposite direction. For example, growth sometimes accelerates during periods of growing uncertainty. Such dynamics occurred over the period 2002-2004 in China; 2004 and 2006 in Germany; 1997, 2003 and 2017 in the UK; or 2018 in the US. Likewise, some periods of declining growth are characterized by attenuating uncertainty. This was the case over the periods 2011-2012 and 2018-2019 in China; 2002-2003 in Germany; 1998, 2004, 2018 in the UK; and 1995, 2011, or 2019 in the US. These facts suggest that a state dependent model which distinguishes between recessions and expansions is not the same as an uncertainty dependent model which differentiates between high and low uncertainty regimes. ${ }^{20}$

\section{Controlling Multipliers'Size for The State of The Economy}

Next, the analysis investigates whether the larger multipliers obtained during periods of high uncertainty instead reflect the effects of economic slack. In that respect, it allows the effects of uncertainty on the multiplier of public investment to vary with the state of the economy by estimating the following specification:

\footnotetext{
${ }^{20}$ The result holds even when using the annual growth rate, rather than the change in the growth rate. In fact, Annex Figure 1 shows that rising uncertainty is not systematically associated with negative annual growth.
} 


$$
\begin{aligned}
y_{i, t+k}-y_{i, t-1} & =\alpha_{i}^{k}+\gamma_{t}^{k}+\beta_{0}^{k} D_{i, t}+\beta_{1}^{k} D_{i, t} G\left(z_{i, t}\right) \Delta I_{i, t}^{+}+\beta_{2}^{k} D_{i, t}\left(1-G\left(z_{i, t}\right)\right) \Delta I_{i, t}^{+}+\beta_{3}^{k}(1 \\
& \left.-D_{i, t}\right) G\left(z_{i, t}\right) \Delta I_{i, t}^{+}+\beta_{4}^{k}\left(1-D_{i, t}\right)\left(1-G\left(z_{i, t}\right)\right) \Delta I_{i, t}^{+}+\theta^{k} M_{i, t}+\varepsilon_{i, t}^{k}
\end{aligned}
$$

where $D_{i, t}$ is a dummy variable indicating whether the economy is in a low or high growth state. Year $t$ is defined as a period of low growth $\left(D_{i, t}=1\right)$ if the growth rate in year $t$ is lower than the average growth rate of the past three years. ${ }^{21}$

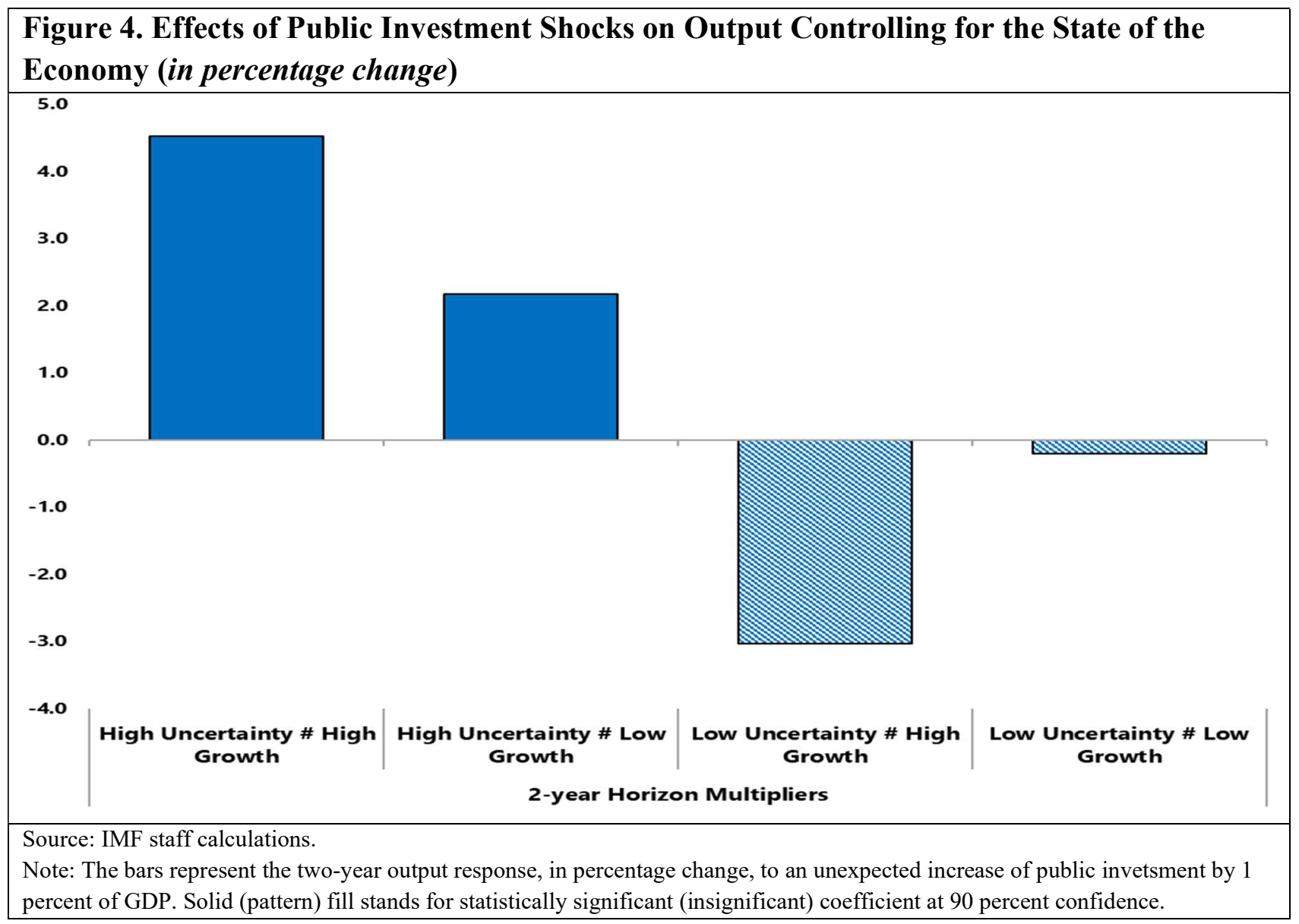

The output responses are presented in Figure 4. The results show that the larger multipliers obtained during periods of high uncertainty are not driven by the state of the. For instance, they reveal that when uncertainty is heightened, public investment shocks have positive and statistically effects on output irrespective to the business cycle (low or high growth states). However, regardless of the state of the economy, the null hypothesis of no effects cannot be rejected when uncertainty is low. The results also show that on average, the multipliers of public investment are lower during periods of low growth compared to periods of high growth and the difference is

\footnotetext{
${ }^{21}$ The main reason for identifying the state of the economy using the real GDP growth instead of the output gap is that the latter is unobservable and subject to substantial and frequent revisions. In a robustness check, we consider unemployment rate as indicator of the state of the economy.
} 
statistically significant (Annex Table 8). These findings suggest that the degree of uncertainty matters for the effects of public investment shocks on the economy.

\section{ROBUSTNESS EXERCISE}

Several robustness exercises are undertaken to assess the sensitivity of the effects of uncertainty on fiscal multipliers to different sample size, alternative definition of investment shock, and different specifications.

We start by assessing whether the main results hold when using a simpler specification. To do so, we use the following specification:

$$
\begin{aligned}
y_{i, t+k}-y_{i, t-1} & =\alpha_{i}^{k}+\gamma_{t}^{k}+\beta_{0}^{k} D_{i, t}+\beta_{1}^{k}\left(1-D_{i, t}\right)+\beta_{2}^{k} D_{i, t} \Delta I_{i, t}^{+}+\beta_{3}^{k}\left(1-D_{i, t}\right) \Delta I_{i, t}^{+} \\
& +\theta^{k} M_{i, t}+\varepsilon_{i, t}^{k} \quad \text { (7) }
\end{aligned}
$$

where $D_{i, t}$ is a dummy variable indicating whether uncertainty is low or high. Year $t$ is defined as a period of high uncertainty $\left(D_{i, t}=1\right)$ if the uncertainty index is higher than the median uncertainty of the sample. The results show that investment multipliers are larger during periods of high uncertainty (See Annex Table 9).

In section IV.D, we use the growth rate to identify the state of the economy. However, Keynesian theories rely on the notion of slack as a stock variable (e.g., how many workers are unemployed) rather than a flow variable (e.g., output growth rate or how many workers are hired or fired). ${ }^{22}$ As a robustness check, we use the unemployment rate to measure the state of the economy employing Equation (5). Country " $i$ " is considered to be in a high unemployment state in year $t\left(D_{i, t}=1\right)$ if the unemployment rate in year $t$ is higher than the average unemployment rate of the past three years. The results confirm that the larger multipliers obtained during periods of high uncertainty are not driven by the state of the economy (Annex Table 10). For instance, during periods of high uncertainty, fiscal multipliers are relatively lower when unemployment rate is high. Moreover, public investment shocks have on average lower effects when implemented during periods of high unemployment.

Annex Table 11 summarizes the results of additional robustness exercises. Panel A shows the results when public investment shocks are defined as the difference between the realized investment and the spring forecast vintage. The conclusions are similar to those discussed above. Public investment multipliers are larger and statistically significant during periods of high uncertainty. The same conclusions are reached when limiting the analysis to the subsample of advanced economies (Panel B), or to the period starting from the Global Financial Crisis (see Panel C). Likewise, the results are robust to the introduction of additional control variables. Panel D indicates that public investment shocks have larger effects on output, investment, and employment during periods of high uncertainty even when controlling for the output gap. Finally, the models

\footnotetext{
${ }^{22}$ For further discussion, refer to Auerbach and Gorodnichenko (2013a).
} 
are estimated using a different value of the curvature of the transition function $\delta$. The results are robust to using $\delta=1.5$ as in Auerbach and Gorodnichenko (2013a). ${ }^{23}$

Overall, these robustness exercises further reinforce the findings that the public investment multiplier is larger during periods of high uncertainty. The analysis here focuses on a simple measure of uncertainty that is available for a large range of countries and captures a broader macroeconomic uncertainty. As discussed above, several types measures of uncertainty have been used in the literature and capture different dimensions of uncertainty, and hence could lead to different results. The type of the uncertainty measure should then be considered when comparing our results to the literature.

\section{Conclusion}

This paper provides empirical evidence on how macroeconomic uncertainty affects the effectiveness of fiscal policy. We find that uncertainty has a positive and significant effect on the public investment multiplier. The results hold after controlling for the business cycle, suggesting that uncertainty matters for the effectiveness of fiscal policy. The paper also sheds light on the role of economic confidence on the transmission of fiscal policy. During periods of heightened uncertainty, public investment surprises boost economic confidence in the short-to-medium-term whereas they weaken confidence when they occurred in periods of low uncertainty. These results suggest that the private sector confidence is important to the transmission of fiscal policy to the economy, as anchoring expectation is for the effectiveness of monetary policy. When the economic outlook is clouded, a public investment push likely signals government commitment to growth and stability hereby improving private agents' expectations about future economic developments. Improved private sector confidence in turn leads to a positive and stronger private response to the initial stimulus. These results are supported by a variety of robustness checks.

Overall, the paper shows that during periods of high uncertainty, the effects of discretionary increases in public investment on output, private investment, and output are magnified due to an indirect channel through which positive investment shocks increase the confidence of households and firms that might otherwise become very cautious and postpone their consumption, hiring, and investment decisions. While these results do not support the "wait-and-see" attitude, they can be reconciled with the theoretical predictions that uncertainty has a negative effect on economic activity (Bloom et al. (2018)). In fact, it is likely that the positive effects of public investment shocks are larger during periods of high uncertainty because private investment is first negatively affected by uncertainty. Therefore, public investment raises private investment by more because private investment starts from a lower level, leading to a larger multiplier.

\footnotetext{
${ }^{23}$ Results for $\delta=0.75$, available upon request, are similar.
} 


\section{REFERENCES}

Abiad, A., Fuceri, D., and Topalova, D. 2016. "The Macroeconomic Effects of Public Investment: Evidence from Advanced Economies.” Journal of Macroeconomics. 50(C): 224-40.

Agénor, P.-R. and Neanidis, K., 2015. Innovation, public capital, and growth, Journal of Macroeconomics, 44, issue C, p. 252-75.

Alesina, A. and S. Ardagna. 2010. "Large Changes in Fiscal Policy: Taxes vs. Spending." Tax Policy and the Economy 24 (October): 35-68.

Alesina, A., C. Favero, and F. Giavazzi (2015). The output effect of fiscal consolidation plans. Journal of International Economics 96, S19-S42.

Alloza, M., 2018. Is fiscal policy more effective in uncertain times or during recessions? Working Papers, No 1730, Banco de España.

Arčabić, V. and Cover, J. 2016.Uncertainty and the effectiveness of fiscal policy, No 1611, EFZG Working Papers Series, Faculty of Economics and Business, University of Zagreb.

Arrow, K. 1962. "Economic Welfare and the Allocation of Resources for Invention", in: National Bureau Committee for Economic Research, Committee on Economic Growth of the Social Science Research Council (eds.), The Rate and Direction of Inventive Activity: Economic and Social Factors, pp. 609-26, Princeton University Press.

Aschauer, D. A. 1989. “Does Public Capital Crowd Out Private Capital?”, Journal of Monetary Economics, Vol. 24, No. 2, pp. 171-88.

Altig, D., Baker, S., Barrero, J. M., Bloom, N., Bunn, P., Chen, S., Davis, S. J., Leather, J., Meyer, B., Mihaylov, E., Mizen, P., Parker, N., Renault, T., Smietanka, P., Thwaites, G. 2020. "Economic Uncertainty Before and During the COVID-19 Pandemic," Journal of Public Economics, Vol 191.

Auerbach, Alan J., William G. Gale, and Benjamin H. Harris. 2010. "Activist Fiscal Policy." Journal of Economic Perspectives, 24 (4): 141-64.

Auerbach, A., and Gorodnichenko, Y. 2012. "Measuring the Output Responses to Fiscal Policy." American Economic Journal: Economic Policy. 4(2): 1-27.

Auerbach, A., and Gorodnichenko, Y. 2013a. "Output Spillovers from Fiscal Policy." American Economic Review. 103(3): 141-146.

Auerbach, A., and Y. Gorodnichenko. 2013b. "Fiscal Multipliers in Recession and Expansion," In Fiscal Policy After the Financial Crisis, edited by Alberto Alesian and Francesco Giavazzi, pp. 63-98. University of Chicago Press.

Azam M., C. Ferré and M. I. Ajwad, 2012. "Did Latvia's Public Works Program Mitigate the Impact of the 2008-10 Crisis?”, World Bank Policy Research Working Paper No. 6144. July 2012. Washington, DC. 
Bachmann, R. and E.R. Sims. 2012. "Confidence and the Transmission of Government Spending Shocks.” Journal of Monetary Economics 59 (3): 235-49.

Bachmann, R., Steffen E., and Sims E.R. 2013. "Uncertainty and Economic Activity: Evidence from Business Survey Data: Dataset.” American Economic Journal: Macroeconomics.

Baker, S. R., Bloom, N., and Davis, S. J. 2016. Measuring economic policy uncertainty. Quarterly Journal of Economics, 131(4):1593-1636.

Baker, S. R., Bloom, N., Davis, S. and Terry, S. J. 2020. COVID-Induced Economic Uncertainty, No 26983, NBER Working Papers, National Bureau of Economic Research, Inc.

Barnichon, R., Debortoli, D. and Matthes, C. 2021. Understanding the size of the government spending multiplier: It's in the sign. The Review of Economic Studies 60.

Barrell, R., D. Holland, and I. Hurst. 2012. "Fiscal Consolidation: Part 2. Fiscal Multipliers and Fiscal Consolidations," OECD Economics Department Working Paper No. 933, Paris.

Barro, R. J. 1974. “Are Government Bonds Net Wealth?” Journal of Political Economy, Vol. 82, No. 6, pp. pp. 1095-1117.

Barsky, R., and Sims, E. 2012. Information, animal spirits, and the meaning of innovations in consumer confidence. American Economic Review, 2012, 102(4): 1343-77.

Batini, N., Eyraud, L., Forni, L., and Weber, A. 2014. "Fiscal Multipliers: Size, Determinants, and Use in Macroeconomics Projections." International Monetary Fund, Technical Notes and Manuals.

Baum, A., M. Poplawski-Ribeiro and A. Weber. 2012. "Fiscal Multipliers and the State of the Economy," IMF Working Paper 12/286. Washington DC. International Monetary Fund.

Baum, C.F., Caglayan, M., and Talavera, O., 2008. Uncertainty determinants of firm investment. Economics Letters 98, 282-87.

Baunsgaard, T. and S. A. Symansky, 2009, “Automatic Stabilizers: How Can They be Enhanced Without Increasing the Size of Government," IMF Staff Position Note 09/23. Washington D.C.

Beaudry, P., and Portier F., 2006. Stock Prices, News, and Economic Fluctuations. The American Economic Review, 96(4), 1293-1307.

Benhabib, J. and R. E. A. Farmer, 1999. "Indeterminacy and Sunspots in Macroeconomics," in John B. Taylor and Michael Woodford, eds., Handbook of macroeconomics. Vol. 1A. Amsterdam: Elsevier Science, North-Holland, 1999, pp. 387-448.

Berg, T. 2019. Business "Uncertainty and the Effectiveness of Fiscal Policy in Germany." Macroeconomic Dynamics 23 (4): 1442-70.

Bernanke, B. S. 1983. "Irreversibility, Uncertainty, and Cyclical Investment." The Quarterly Journal of Economics, February 1983, Vol. 98, No. 1, pp. 85-106. 
Blanchard, O., and Leigh D. 2013. Growth Forecast Errors and Fiscal Multipliers. American Economic Review 103 (3): 117-20.

Blanchard, O., and Perotti, R. 2002. "An Empirical Characterization of the Dynamic Effects of Changes in Government Spending and Taxes on Output." The Quarterly Journal of Economics. 117(4): 1329-68.

Bloom, N. 2009. The Impact of Uncertainty Shocks. Econometrica, 77(3):623-85.

Bloom, N. 2014."Fluctuations in uncertainty." The Journal of Economic Perspectives 28.2, pp.153-75.

Bloom, N., Floetotto, M., Jaimovich, N., Saporta-Eksten, I., and Terry, S. J. 2018. Really uncertain business cycles. Econometrica, 86(3):1031-65.

Bloom, N., Stephen B., and Reenen J. 2007. "Uncertainty and Investment Dynamics."Review of Economic Studies 74 (2): 391-415.

Boero G., Jeremy S., and Wallis K. 2008. "Uncertainty and Disagreement in Economic Prediction: The Bank of England Survey of External Forecasters.” Economic Journal 118 (530): 1107 27.

Bomberger, W. A. 1996. "Disagreement as a Measure of Uncertainty." Journal of Money, Credit and Banking 28 (3): 381-92.

Bond, S., and Cummins J. 2004. "Uncertainty and Investment: An Empirical Investigation Using Data on Analysts' Profits Forecasts."

Born, B., Juessen F., and Müller G. J. 2013. "Exchange Rate Regimes and Fiscal Multipliers." Journal of Economic Dynamics and Control 37(2): 446-65.

Bunn, P., Le Roux, J., Reinold, K. and Surico, P. 2018. The consumption response to positive and negative income shocks, Journal of Monetary Economics, 96, issue C, p. 1-15,

Carroll, C. 2003. Macroeconomic Expectations of Households and Professional Forecasters, The Quarterly Journal of Economics,118, issue 1, p. 269-98.

Carroll, C., Fuhrer, J., and Wilcox, D., 1994. Does consumer sentiment forecast household spending? If so, why? American Economic Review 85 (5), 1397-1408.

Christiano, L., Eichenbaum M., and Rebelo S. 2011. "When Is the Government Spending Multiplier Large?" J.P.E. 119 (1): 78-121.

Clements, M. P. 2008. "Consensus and Uncertainty: Using Forecast Probabilities of Output Declines." International Journal of Forecasting 24 (1): 76-86.

Cochrane, J., 2009. Fiscal Stimulus, Fiscal Inflation, or Fiscal Fallacies? Available at https://faculty.ses.wsu.edu/RayB/420/fiscal_stimulus.pdf.

Coenen, G, Erceg C., Freedman C., Furceri D., Kumhof M., Lalonde R., Laxton D., Lindé J., Mourougane A., Muir D., Mursula S., de Resende C., Roberts J., Roeger W., Snudden S., 
Trabandt M. and in 't Veld J. 2012. Effects of Fiscal Stimulus in Structural Models, American Economic Journal: Macroeconomics, 4, issue 1, p. 22-68.

Cogan, J. F., Tobias C, Taylor J. B., and Wieland V. 2010. "New Keynesian versus Old Keynesian Government Spending Multipliers.” J. Econ. Dynamics and Control 34:281-95.

Congressional Budget Office. 2015. Estimated Impact of the American Recovery and Reinvestment Act on Employment and Economic Output in 2014. Publication No. 49958. Washington, DC.

Cournède, B. and Denk O. 2015. "Finance and Economic Growth in OECD and G20 Countries", OECD Economics Department Working Papers, No. 1223, OECD Publishing, Paris.

Crafts, N. and Mills, T. C. 2013. Fiscal Policy in a Depressed Economy: Was There a 'Free Lunch' in 1930s' Britain? (January 2013). CEPR Discussion Paper No. DP9273.

Dixit, A. and Pindyck, R., 1994. Investment under Uncertainty, 1 ed., Princeton University Press.

Dolls, M., Fuest, C. and Peichl, A., 2012. "Automatic Stabilizers and Economic Crisis: US vs. Europe," Journal of Public Economics, Vol. 96, pp. 279-94.

Farmer, R. 2010. 10 Questions: Economist Roger Farmer. UCLA Today.

Fatás, A. and Summers L. H., 2018. The permanent effects of fiscal consolidations. Journal of International Economics, Volume 112, 2018, Pages 238-50.

Federer, J. P. 1993. “Does Uncertainty Affect Investment Spending?” Journal of Post Keynesian Economics 16 (1): 19-35.

Feldstein, M. 2008. Our economic dilemma. Wall Street Journal, A15.

Forni, M., and Gambetti, L., 2010. Fiscal Foresight and the Effects of Government Spending. Centre for Economic Policy Research Discussion Paper 7840.

Fournier J.-M., 2016. "The Positive Effect of Public Investment on Potential Growth," OECD Economics Department Working Papers 1347, OECD Publishing.

Fuss, C., and P. Vermeulen. 2008. "Firms' Investment Decisions in Response to Demand and Price Uncertainty." Applied Economics 40 (16-18): 2337-51.

Galí, J., Lopez-Salido, D., and Valles, J. 2007. Understanding the Effects of Government Spending on Consumption,Journal of the European Economic Association, 5, issue 1, p. 227-70.

Gbohoui, W. 2019. Do Temporary Business Tax Cuts Matter? A General Equilibrium Analysis. IMF Working Paper No. 19/29. International Monetary Fund, Washington

Gechert, S. 2015. "What Fiscal Policy is Most Effective? A Meta-Regression Analysis. Oxford Economic Papers. 67(3): 553-80.

Gechert, S., and Rannenberg, A. 2018. "Which Fiscal Multipliers are Regime-Dependent? A MetaRegression Analysis." Journal of Economic Surveys. 32(4): 1160-82. 
Giordano, P., and Söderlind P. 2003. "Inflation Forecast Uncertainty." European Economic Review 47 (6): 1037-59.

Guimaraes, B., C. Machado, and M. Ribeiro (2016). A model of the con_dence channel of_scal policy. Journal of Money, Credit and Banking 48 (7), pages 1363-1395.

Guiso, L., and Parigi, G. 1999. "Investment and Demand Uncertainty." Quarterly Journal of Economics. 114: 185-227.

Gurara, D., Kpodar, K., Presbitero, A.F., and Tessema, D. 2020. On the capacity to absorb public investment: how much is too much? IMF WP/20/48

Heathcote, J. 2005, "Fiscal Policy with Heterogeneous Agents and Incomplete Markets," Review of Economic Studies, Vol. 72, No. 1, pp. 161-88.

Huidrom, R., Kose, A., Lim, J. and Ohnsorge, F. 2020. Why do fiscal multipliers depend on fiscal Positions?,Journal of Monetary Economics, 114, issue C, p. 109-25.

Ilzetzki, E., Mendoza, E., and Vegh, C. 2013. "How big (small?) are fiscal multipliers?” Journal of Monetary Economics. 60: 239-54.

International Monetary Fund. 2008. World Economic Outlook, October, Chapter 5, "Fiscal Policy as a Countercyclical Tool" Washington, D.C.

International Monetary Fund. 2014. "It is Time for an Infrastructure Push? The Macroeconomic Effects of Public Investment." World Economic Outlook, Chapter 3, October 2014. Washington, D.C.

International Monetary Fund 2020a. "Public Investment for the Recovery". Fiscal Monitor, Chapter 2, October 2020, Washington, D.C.

International Monetary Fund 2020b. "Countering Future Recessions in Advanced Economies: Cyclical Policies in an Era of Low Rates and High Debt". World Economic Outlook, Chapter 2, April 2020, Washington, D.C.

International Monetary Fund 2021. "Policy Support and Vaccines Expected to Lift Activity." World Economic Outlook Update, January 2021, Washington, D.C.

Johansson, 2016. "Public Finance, Economic Growth and Inequality: A Survey of the Evidence", OECD. Economics Department Working Papers, No. 1346, OECD Publishing, Paris.

Jorda, O. 2005. "Estimation and Inference of Impulse Responses by Local Projections." American Economic Review. 95(1): 161-82.

Kang, W., Leeb, K., and Rattic., R. 2014. "Economic policy uncertainty and firm-level investment.” Journal of Macroeconomics. 39: 42-53.

Koh, W. C., 2017. Fiscal multipliers: new evidence from a large panel of countries, Oxford Economic Papers, 69, issue 3, p. 569-590

Leeper, E.M., Richter, A.W., and Walker, T.B. 2012. "Quantitative Effects of Fiscal Foresight." American Economic Journal: Economic Policy, 4 (2): 115-44. 
Leeper, E.M., Walker, T.B., and Yang, S. 2013. "Fiscal Foresight and Information Flows." Econometrica, 81(3): 1115-45.

Mineshima, A., M. Poplawski-Ribeiro, and A. Weber, 2014, "Size of Fiscal Multipliers", in Postcrisis Fiscal Policy, ed. by C. Cottarelli, P. Gerson, and A. Senhadji, volume 1, pages 315372. The MIT Press.

Miyamoto W., Nguyen, T.L., and Sergeyev, D. 2018. “Government Spending Multipliers under the Zero Lower Bound: Evidence from Japan”. American Economic Journal: Macroeconomics. 10 (3): 247-77.

Miyamoto, H, Gueorguiev, N., Honda, J., Baum, A and Walker S. 2020. Growth Impact of Public Investment and the Role of Infrastructure Governance. International Monetary Fund, Washington, D.C.

Moretti E., Steinwender C., and Reenen J. V. 2019. "The Intellectual Spoils of War? Defense R\&D, Productivity and International Spillovers," NBER Working Papers 26483.

Mountford, A., Uhlig, H. 2009. What are the effects of fiscal policy shocks? Journal of Applied Econometrics 24 (6), 960-92

Nickel, C., and Tudyka A. 2014. "Fiscal Stimulus in Times of High Debt: Reconsidering Multipliers and Twin Deficits.” Journal of Money, Credit and Banking 46(7): 1313-44.

Petrović, P., Arsić, M. and Nojković A. 2021. Increasing public investment can be an effective policy in bad times: Evidence from emerging EU economies. Economic Modelling 94, 580-597.

Popescu, A., and Smets F. R. 2010. "Uncertainty, Risk-Taking, and the Business Cycle in Germany.” CESifo Economic Studies 56 (4): 596-626.

Presbitero, A. 2016. 'Too much and too fast? Public investment Scaling-up and Absorptive Capacity', Journal of Development Economics 120, 17-31

Ramey, V. A. 2011. "Identifying government spending shocks: It's all in the timing." The Quarterly Journal of Economics. 126(1): 1-50.

Ramey, V. A. 2019. "Ten Years after the Financial Crisis: What Have We Learned from the Renaissance in Fiscal Research?”. Journal of Economic Perspectives. 33 (2): 89-114.

Ramey, V., and Zubairy, S. 2018. "Government Spending Multipliers in Good Times and in Bad: Evidence from U.S. Historical Data.” Journal of Political Economy. 126 (2): 850-901.

Rich R., and Tracy J. 2010. “The Relationships among Expected Inflation, Disagreement, and Uncertainty: Evidence from Matched Point and Density Forecasts." Review of Economics and Statistics 92 (1): 200-07.

Riera-Crichton, D., Vegh C. A., and Vuletin G. 2015."Procyclical and countercyclical fiscal multipliers: Evidence from OECD countries." Journal of International Money and Finance 52, pp. 15-31. 
Romer, C. D., and D. H. Romer. 2010. The Macroeconomic Effects of Tax Changes: Estimates Based on a New Measure of Fiscal Shocks. American Economic Review, 100 (3): 763801.

Romer, P. 1986. "Increasing Returns and Long-Run Growth", The Journal of Political Economy, Vol. 94, No. 5, pp. 1002-1037.

Spiegel H. W. 1991.The Growth of Economic Thought. Third Edition, Duke University Press. p.189, Durham and London.

Spilimbergo, A., Symansky, S., and M. Schindler, 2009, "Fiscal Multipliers," IMF Staff Position Note, SPN/09/11, May 2009. International Monetary Fund, Washington, D.C.

Zarnovitz, V., and Lambros L. A. 1987. "Consensus and Uncertainty in Economic Prediction." Journal of Political Economy 95 (3): 591-621.

Zeev, N.B., and Pappa, E. 2015. "Chronicle of a War Foretold: The Macroeconomic Effects of Anticipated Defense Spending Shocks.” The Economic Journal. 127(603): 1568-97.

Zimmermann L. 2020. "Why Guarantee Employment? Evidence from a Large Indian PublicWorks Program”, GLO Discussion Paper 504. Essen, Germany. 
ANNEX

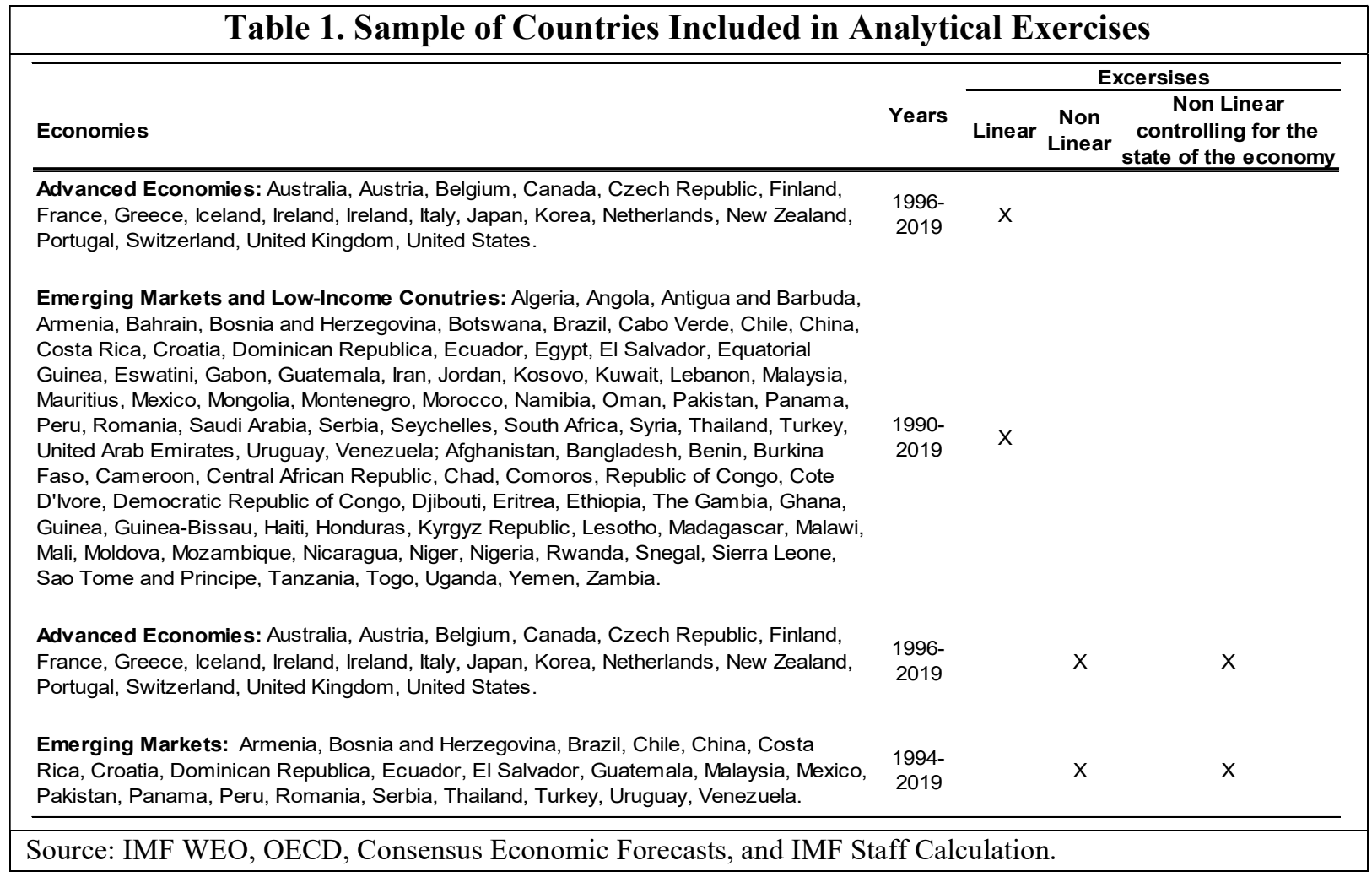

\begin{tabular}{|c|c|c|c|c|c|c|c|c|c|}
\hline \multirow[b]{2}{*}{ Dependent variable: Output } & \multicolumn{3}{|c|}{ Whole sample } & \multicolumn{3}{|c|}{ Advanced Economies } & \multicolumn{3}{|c|}{ Emerging and Developping Economies } \\
\hline & $\mathrm{k}=0$ & $k=1$ & $\mathrm{k}=2$ & $k=0$ & $k=1$ & $\mathrm{k}=2$ & $k=0$ & $\mathrm{k}=1$ & $\mathrm{k}=2$ \\
\hline Public investment shock & $\begin{array}{c}\mathbf{0 . 2 3 3 5 * * *} \\
(0.0807)\end{array}$ & $\begin{array}{c}\mathbf{0 . 5 8 2 2 * * *} \\
(0.1007)\end{array}$ & $\begin{array}{c}0.5247^{* * *} \\
(0.1877)\end{array}$ & $\begin{array}{c}0.5510^{* *} \\
(0.2336)\end{array}$ & $\begin{array}{c}0.7030 \\
(0.7856)\end{array}$ & $\begin{array}{l}\mathbf{0 . 0 7 3 7} \\
(1.5017)\end{array}$ & $\begin{array}{l}0.2202^{*} \\
(0.1115)\end{array}$ & $\begin{array}{c}0.5863^{* * *} \\
(0.1109)\end{array}$ & $\begin{array}{r}0.5569^{* *} \\
(0.2191)\end{array}$ \\
\hline Lag of Public investment shoch & $\begin{array}{l}0.5910^{*} \\
(0.3101)\end{array}$ & $\begin{array}{c}0.4580 \\
(0.2915)\end{array}$ & $\begin{array}{c}0.3495 \\
(0.3140)\end{array}$ & $\begin{array}{c}0.3614 \\
(0.3375)\end{array}$ & $\begin{array}{c}0.3193 \\
(0.6033)\end{array}$ & $\begin{array}{c}0.3375 \\
(0.8758)\end{array}$ & $\begin{array}{l}0.6083^{*} \\
(0.3571)\end{array}$ & $\begin{array}{c}0.4695 \\
(0.3346)\end{array}$ & $\begin{array}{c}0.3551 \\
(0.3556)\end{array}$ \\
\hline Lag of real GDP growth rate & $\begin{array}{l}-0.0028 \\
(0.0024)\end{array}$ & $\begin{array}{l}-0.0021 \\
(0.0018)\end{array}$ & $\begin{array}{l}-0.0017 \\
(0.0011)\end{array}$ & $\begin{array}{c}0.0011 \\
(0.0016)\end{array}$ & $\begin{array}{c}0.0015 \\
(0.0027)\end{array}$ & $\begin{array}{c}0.0024 \\
(0.0037)\end{array}$ & $\begin{array}{l}-0.0036 \\
(0.0027)\end{array}$ & $\begin{array}{l}-0.0027 \\
(0.0020)\end{array}$ & $\begin{array}{c}-0.0024^{* *} \\
(0.0009)\end{array}$ \\
\hline Constant & $\begin{array}{l}-0.0579^{\star} \\
(0.0298)\end{array}$ & $\begin{array}{c}-0.0763^{* *} \\
(0.0382)\end{array}$ & $\begin{array}{l}-0.0532 \\
(0.0485)\end{array}$ & $\begin{array}{c}0.0269^{\star \star *} \\
(0.0052)\end{array}$ & $\begin{array}{c}0.0605^{\star \star \star} \\
(0.0124)\end{array}$ & $\begin{array}{c}0.1024^{\star \star \star} \\
(0.0193)\end{array}$ & $\begin{array}{l}-0.0565 \\
(0.0357)\end{array}$ & $\begin{array}{l}-0.0683 \\
(0.0462)\end{array}$ & $\begin{array}{l}-0.0361 \\
(0.0586)\end{array}$ \\
\hline $\begin{array}{l}\text { Observations } \\
\text { R-squared }\end{array}$ & $\begin{array}{c}389 \\
0.5533\end{array}$ & $\begin{array}{c}389 \\
0.7220\end{array}$ & $\begin{array}{c}389 \\
0.7387\end{array}$ & $\begin{array}{c}213 \\
0.7325\end{array}$ & $\begin{array}{c}213 \\
0.7249\end{array}$ & $\begin{array}{c}213 \\
0.7135\end{array}$ & $\begin{array}{c}176 \\
0.4883\end{array}$ & $\begin{array}{c}176 \\
0.7205\end{array}$ & $\begin{array}{c}176 \\
0.7533\end{array}$ \\
\hline
\end{tabular}




\begin{tabular}{|c|c|c|c|c|c|c|c|c|c|}
\hline \multirow[t]{2}{*}{ Depdent variable: Private Investment } & \multicolumn{3}{|c|}{ Whole sample } & \multicolumn{3}{|c|}{ Advanced Economies } & \multicolumn{3}{|c|}{ Emerging and Developping Economies } \\
\hline & $\mathbf{k}=\mathbf{0}$ & $k=1$ & $\mathrm{k}=\mathbf{2}$ & $\mathbf{k}=\mathbf{0}$ & $\mathrm{k}=1$ & $\mathrm{k}=\mathbf{2}$ & $k=0$ & $\mathrm{k}=1$ & $\mathbf{k}=\mathbf{2}$ \\
\hline Public investment shock & $\begin{array}{c}\mathbf{1 . 1 6 1 1} \\
(1.0091)\end{array}$ & $\begin{array}{c}\text { 3.2018*** } \\
(0.7399)\end{array}$ & $\begin{array}{c}3.6812^{* * *} \\
(0.7911)\end{array}$ & $\begin{array}{c}3.5494 \\
(2.7993)\end{array}$ & $\begin{array}{c}5.9359 \\
(4.0480)\end{array}$ & $\begin{array}{c}\mathbf{3 . 4 3 6 0} \\
(5.2732)\end{array}$ & $\begin{array}{c}\mathbf{1 . 0 7 4 8} \\
(1.1647)\end{array}$ & $\begin{array}{c}\text { 3.1126*** } \\
(0.7918)\end{array}$ & $\begin{array}{c}3.7240^{* * *} \\
(0.8235)\end{array}$ \\
\hline Lag of Public investment shock & $\begin{array}{l}1.9166^{* \star} \\
(0.7635)\end{array}$ & $\begin{array}{l}1.5879^{\star} \\
(0.9430)\end{array}$ & $\begin{array}{c}1.0084 \\
(1.0700)\end{array}$ & $\begin{array}{c}1.0410 \\
(0.9725)\end{array}$ & $\begin{array}{c}0.6190 \\
(1.9764)\end{array}$ & $\begin{array}{l}-0.9432 \\
(3.8535)\end{array}$ & $\begin{array}{l}1.9480^{* *} \\
(0.9314)\end{array}$ & $\begin{array}{c}1.6031 \\
(1.1380)\end{array}$ & $\begin{array}{c}1.0701 \\
(1.2794)\end{array}$ \\
\hline Lag of real GDP growth rate & $\begin{array}{c}0.0075 \\
(0.0099)\end{array}$ & $\begin{array}{l}0.0023 \\
(0.0051)\end{array}$ & $\begin{array}{c}0.0014 \\
(0.0051)\end{array}$ & $\begin{array}{c}0.0048 \\
(0.0038)\end{array}$ & $\begin{array}{l}-0.0074 \\
(0.0101)\end{array}$ & $\begin{array}{l}-0.0123 \\
(0.0172)\end{array}$ & $\begin{array}{c}0.0081 \\
(0.0131)\end{array}$ & $\begin{array}{l}0.0042 \\
(0.0068)\end{array}$ & $\begin{array}{c}0.0042 \\
(0.0059)\end{array}$ \\
\hline Constant & $\begin{array}{l}1.8739^{\star \star *} \\
(0.0665)\end{array}$ & $\begin{array}{l}1.6635^{\star \star \star} \\
(0.1284)\end{array}$ & $\begin{array}{l}1.5403^{\star \star \star} \\
(0.1710)\end{array}$ & $\begin{array}{c}0.0053 \\
(0.0199)\end{array}$ & $\begin{array}{l}0.0883^{*} \\
(0.0507)\end{array}$ & $\begin{array}{l}0.1773^{* *} \\
(0.0790)\end{array}$ & $\begin{array}{l}1.8874^{\star \star *} \\
(0.0827)\end{array}$ & $\begin{array}{l}1.6918^{\star \star \star} \\
(0.1569)\end{array}$ & $\begin{array}{l}1.5810^{\star \star \star} \\
(0.1999)\end{array}$ \\
\hline Observations & 386 & 386 & 386 & 213 & 213 & 213 & 173 & 173 & 173 \\
\hline R-squared & 0.6480 & 0.6437 & 0.6349 & 0.4999 & 0.5109 & 0.4955 & 0.6667 & 0.6761 & 0.6834 \\
\hline
\end{tabular}

Source: IMF staff calculations. All regressions control for year and country fixed effects. Clustered robust standard errors in parentheses. ${ }^{*} \mathrm{p}<.10 ; * * \mathrm{p}<.05 ; * * * \mathrm{p}<.01$.

\begin{tabular}{|c|c|c|c|c|c|c|c|c|c|}
\hline \multirow[t]{2}{*}{ Dependent variable: Employment } & \multicolumn{3}{|c|}{ Whole sample } & \multicolumn{3}{|c|}{ Advanced Economies } & \multicolumn{3}{|c|}{ Emerging and Developping Economies } \\
\hline & $k=0$ & $k=1$ & $k=2$ & $k=0$ & $k=1$ & $k=2$ & $k=0$ & $k=1$ & $k=2$ \\
\hline \multirow{2}{*}{ Public investment shock } & -0.0248 & 0.0587 & 0.5528 & $0.5302^{*}$ & 0.8508 & 0.8189 & -0.3546 & -0.3046 & 0.5207 \\
\hline & $(0.3533)$ & $(0.4175)$ & $(0.4610)$ & $(0.2743)$ & $(0.6338)$ & $(0.9696)$ & $(0.5849)$ & $(0.6471)$ & $(0.7797)$ \\
\hline \multirow[t]{2}{*}{ Lag of Public investment shock } & 0.3050 & $0.7170^{\star}$ & 0.6047 & 0.3576 & 0.7259 & 0.5421 & 0.1284 & 0.5465 & 0.6153 \\
\hline & $(0.3318)$ & $(0.4252)$ & $(0.4348)$ & $(0.2633)$ & $(0.4831)$ & $(0.7746)$ & $(0.4232)$ & $(0.5929)$ & $(0.6712)$ \\
\hline \multirow[t]{2}{*}{ Lag of real GDP growth rate } & $0.0042^{\star \star \star}$ & $0.0045^{\star \star \star}$ & $0.0044^{\star \star *}$ & $0.0032^{\star \star \star}$ & $0.0044^{\star *}$ & $0.0054^{*}$ & $0.0049^{* *}$ & 0.0041 & 0.0032 \\
\hline & $(0.0014)$ & $(0.0015)$ & $(0.0016)$ & $(0.0011)$ & $(0.0020)$ & $(0.0029)$ & $(0.0024)$ & $(0.0026)$ & $(0.0027)$ \\
\hline \multirow[t]{2}{*}{ Constant } & $-0.0485^{\star}$ & $-0.1048^{* *}$ & -0.1002 & -0.0067 & -0.0018 & 0.0132 & -0.0141 & -0.0681 & -0.0966 \\
\hline & $(0.0270)$ & $(0.0438)$ & $(0.0612)$ & $(0.0057)$ & $(0.0093)$ & $(0.0153)$ & $(0.0411)$ & $(0.0753)$ & $(0.1184)$ \\
\hline Observations & 311 & 311 & 310 & 213 & 213 & 213 & 98 & 98 & 97 \\
\hline R-squared & 0.5329 & 0.5800 & 0.6426 & 0.6347 & 0.6203 & 0.5810 & 0.4680 & 0.5189 & 0.6997 \\
\hline
\end{tabular}

Source: IMF staff calculations. All regressions control for year and country fixed effects. Clustered robust standard errors in parentheses. ${ }^{*} \mathrm{p}<.10 ; *{ }^{*} \mathrm{p}<.05 ; * * * \mathrm{p}<.01$.

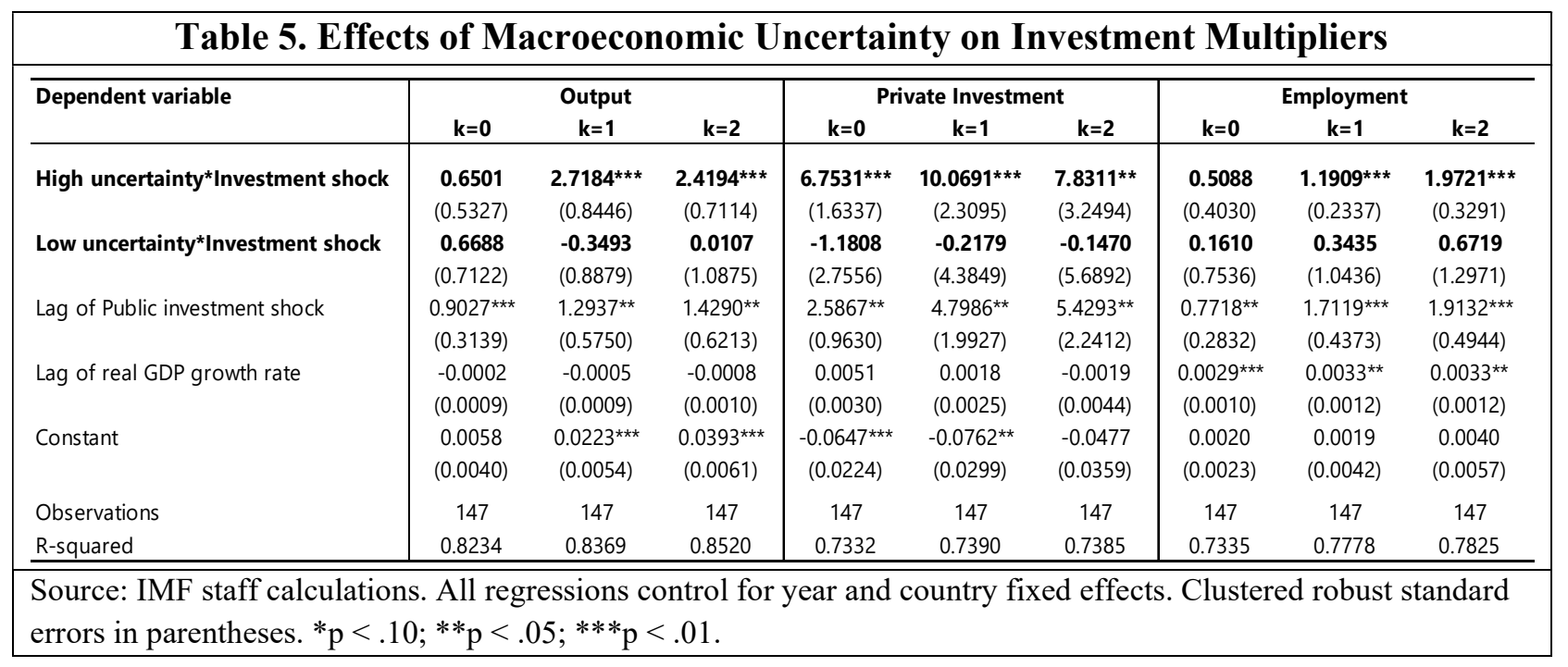




\begin{tabular}{|c|c|c|c|c|c|c|}
\hline \multicolumn{7}{|c|}{ Table 6. Linear Effects of Public Investment Shocks on Confidence } \\
\hline \multirow[t]{2}{*}{ Dependent variable } & \multicolumn{3}{|c|}{ Mean Forecast of GDP } & \multicolumn{3}{|c|}{ Standard Deviation of GDP Forecast } \\
\hline & $k=1$ & $k=2$ & $k=3$ & $k=1$ & $k=2$ & $k=3$ \\
\hline \multirow[t]{2}{*}{ Public investment shock } & $0.5417^{*}$ & 0.1756 & 0.6620 & -0.0362 & -0.1590 & -0.0388 \\
\hline & $(0.2929)$ & $(0.3389)$ & $(0.4670)$ & $(0.1077)$ & $(0.1322)$ & $(0.1196)$ \\
\hline \multirow[t]{2}{*}{ Lag of Public investment shock } & -0.1682 & 0.1506 & $-0.3519^{*}$ & $-0.0820^{*}$ & -0.0775 & -0.0339 \\
\hline & $(0.2212)$ & $(0.2079)$ & $(0.1884)$ & $(0.0444)$ & $(0.0647)$ & $(0.0370)$ \\
\hline \multirow[t]{2}{*}{ Lag of real GDP growth rate } & $-0.0030^{* * *}$ & $-0.0018^{*}$ & $-0.0037^{\star * *}$ & $0.0002^{*}$ & $0.0003^{\star * *}$ & $0.0002^{\star *}$ \\
\hline & $(0.0004)$ & $(0.0009)$ & $(0.0009)$ & $(0.0001)$ & $(0.0001)$ & $(0.0001)$ \\
\hline \multirow[t]{2}{*}{ Constant } & $-0.0550^{* * *}$ & $-0.0538^{\star * *}$ & $-0.0459^{\star * *}$ & $0.0197^{\star * *}$ & $0.0198^{\star * *}$ & $0.0196^{* * *}$ \\
\hline & $(0.0045)$ & $(0.0056)$ & $(0.0057)$ & $(0.0048)$ & $(0.0041)$ & $(0.0026)$ \\
\hline Observations & 147 & 137 & 133 & 144 & 134 & 130 \\
\hline R-squared & 0.9036 & 0.8556 & 0.8539 & 0.8779 & 0.7518 & 0.8619 \\
\hline
\end{tabular}

\begin{tabular}{|l|ccc|ccc|}
\hline \multicolumn{6}{|c|}{ Table 7. Nonlinear Effects of Public Investment Shocks on Confidence } \\
\hline Dependent variable & \multicolumn{5}{c}{ Mean Forecast of GDP } & \multicolumn{3}{c|}{ Standard Deviation of GDP Forecast } \\
& $k=1$ & $k=2$ & $k=3$ & $k=1$ & $k=2$ & $k=3$ \\
\hline \multirow{2}{*}{ High uncertainty*Investment shoc } & $3.1377^{* * *}$ & $2.4207^{* * *}$ & $2.1909^{* * *}$ & $-0.8800^{* * *}$ & $-1.0797^{* * *}$ & $-0.8850^{* * *}$ \\
& $(0.3969)$ & $(0.3652)$ & $(0.5280)$ & $(0.0738)$ & $(0.1143)$ & $(0.0756)$ \\
Low uncertainty*Investment shock & $-1.9205^{* * *}$ & $-1.9936^{* * *}$ & $-1.2212^{*}$ & $0.7755^{* * *}$ & $0.7634^{* * *}$ & $0.7687^{* * *}$ \\
& $(0.5451)$ & $(0.5308)$ & $(0.6588)$ & $(0.0702)$ & $(0.1119)$ & $(0.1322)$ \\
Lag of Public investment shock & -0.2207 & 0.0848 & $-0.4108^{*}$ & $-0.0768^{* * *}$ & -0.0636 & -0.0370 \\
& $(0.3084)$ & $(0.2374)$ & $(0.2187)$ & $(0.0219)$ & $(0.0629)$ & $(0.0247)$ \\
Lag of real GDP growth rate & $-0.0027^{* * *}$ & -0.0015 & $-0.0033^{* * *}$ & 0.0000 & $0.0001^{*}$ & 0.0001 \\
& $(0.0004)$ & $(0.0009)$ & $(0.0008)$ & $(0.0001)$ & $(0.0001)$ & $(0.0001)$ \\
Constant & $-0.0536^{* * *}$ & $-0.0511^{* * *}$ & $-0.0437^{* * *}$ & $0.0193^{* * *}$ & $0.0187^{* * *}$ & $0.0187^{* * *}$ \\
& $(0.0042)$ & $(0.0079)$ & $(0.0067)$ & $(0.0047)$ & $(0.0039)$ & $(0.0025)$ \\
Observations & 145 & 135 & 131 & 144 & 134 & 130 \\
R-squared & 0.9171 & 0.8693 & 0.8625 & 0.9146 & 0.8272 & 0.9203 \\
\hline
\end{tabular}

Source: IMF staff calculations. All regressions control for year and country fixed effects. Clustered robust standard errors in parentheses. ${ }^{*} \mathrm{p}<.10 ; * * \mathrm{p}<.05 ; * * * \mathrm{p}<.01$. 
Figure 1. Change in Uncertainty and Real GDP Growth Rate
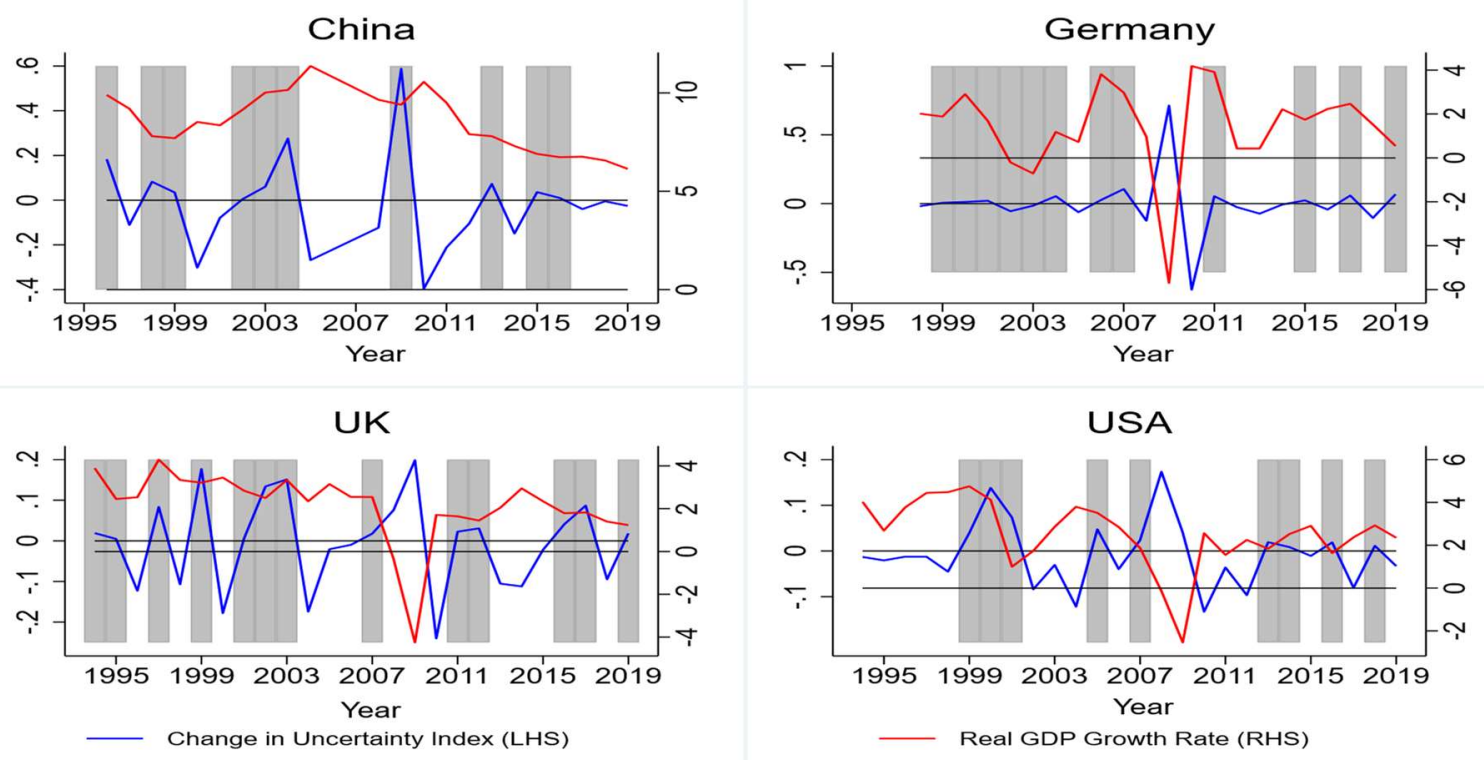

Source: Consensus Economics Forecasts, IMF WEO, and Authors' calculations.

Note: The figure shows the change in uncertainty (standard deviation of spring vintage of current year's GDP growth forecasts across professional forecasters by Consensus Economics) and the real GDP growth.

\begin{tabular}{|c|c|c|c|c|c|c|c|c|c|}
\hline \multirow{2}{*}{ Dependent variable } & \multicolumn{3}{|c|}{ Output } & \multicolumn{3}{|c|}{ Private Investment } & \multicolumn{3}{|c|}{ Employment } \\
\hline & $k=0$ & $\mathrm{k}=1$ & $k=2$ & $k=0$ & $k=1$ & $\mathrm{k}=2$ & $k=0$ & $k=1$ & $k=2$ \\
\hline Low (diff. VS high) growth period (Dummy=1) & $\begin{array}{c}-0.0178^{* * *} \\
(0.0062)\end{array}$ & $\begin{array}{c}-0.0308^{* * *} \\
(0.0078)\end{array}$ & $\begin{array}{c}-0.0349 * * * \\
(0.0098)\end{array}$ & $\begin{array}{l}-0.0371 \\
(0.0220)\end{array}$ & $\begin{array}{l}-0.0519 \\
(0.0353)\end{array}$ & $\begin{array}{c}-0.0908^{* *} \\
(0.0433)\end{array}$ & $\begin{array}{l}-0.0028 \\
(0.0041)\end{array}$ & $\begin{array}{c}-0.0138^{* *} \\
(0.0063)\end{array}$ & $\begin{array}{c}-0.0237^{* * *} \\
(0.0079)\end{array}$ \\
\hline High uncertainty \# High growth & $\begin{array}{l}3.3101^{* *} \\
(1.4446)\end{array}$ & $\begin{array}{l}4.5245^{*} \\
(2.6008)\end{array}$ & $\begin{array}{l}4.3036 \\
(6.1230)\end{array}$ & $\begin{array}{l}14.1172^{*} \\
(7.7499)\end{array}$ & $\begin{array}{r}15.3748 \\
(11.0447)\end{array}$ & $\begin{array}{c}6.2032 \\
(14.7920)\end{array}$ & $\begin{array}{c}\mathbf{0 . 8 1 5 4} \\
(1.7119)\end{array}$ & $\begin{array}{r}1.6509 \\
(3.1529)\end{array}$ & $\begin{array}{c}0.5822 \\
(4.7411)\end{array}$ \\
\hline High uncertainty \# Low growth & $\begin{array}{r}0.2486 \\
(0.6965)\end{array}$ & $\begin{array}{c}2.1650^{* * *} \\
(0.6000)\end{array}$ & $\begin{array}{c}1.7493^{* * *} \\
(0.5984)\end{array}$ & $\begin{array}{c}5.4095^{* * *} \\
(1.2669)\end{array}$ & $\begin{array}{c}7.9843^{* * *} \\
(2.0476)\end{array}$ & $\begin{array}{l}5.8199 * * \\
(2.1664)\end{array}$ & $\begin{array}{c}0.4235 \\
(0.4514)\end{array}$ & $\begin{array}{l}0.9368^{* *} \\
(0.3497)\end{array}$ & $\begin{array}{c}1.7187^{* * *} \\
(0.3621)\end{array}$ \\
\hline Low uncertainty \# High growth & $\begin{array}{l}-2.0134^{*} \\
(1.1056)\end{array}$ & $\begin{array}{l}-3.0364 \\
(2.0739)\end{array}$ & $\begin{array}{l}-2.8781 \\
(4.5623)\end{array}$ & $\begin{array}{l}-7.7034 \\
(6.3953)\end{array}$ & $\begin{array}{l}-5.4625 \\
(8.7795)\end{array}$ & $\begin{array}{c}-2.6034 \\
(10.6443)\end{array}$ & $\begin{array}{l}-0.1590 \\
(1.4374)\end{array}$ & $\begin{array}{l}-0.6002 \\
(2.4804)\end{array}$ & $\begin{array}{r}0.5171 \\
(3.3893)\end{array}$ \\
\hline Low uncertainty \# Low growth & $\begin{array}{r}0.8569 \\
(1.2667)\end{array}$ & $\begin{array}{l}-0.2099 \\
(1.4479)\end{array}$ & $\begin{array}{l}-0.0906 \\
(1.5956)\end{array}$ & $\begin{array}{l}-2.6698 \\
(3.0630)\end{array}$ & $\begin{array}{l}-4.8635 \\
(4.2047)\end{array}$ & $\begin{array}{l}-3.7441 \\
(3.7253)\end{array}$ & $\begin{array}{c}0.0475 \\
(0.9239)\end{array}$ & $\begin{array}{c}0.2717 \\
(1.2500)\end{array}$ & $\begin{array}{c}\mathbf{0 . 7 5 1 2} \\
(1.4396)\end{array}$ \\
\hline Lag of Public investment shock & $\begin{array}{l}0.6993^{\star \star \star} \\
(0.2169)\end{array}$ & $\begin{array}{l}1.0621^{\text {** }} \\
(0.4547)\end{array}$ & $\begin{array}{l}1.1560^{* *} \\
(0.5515)\end{array}$ & $\begin{array}{l}1.9430^{\star *} \\
(0.8800)\end{array}$ & $\begin{array}{l}3.9562^{\star \star} \\
(1.8282)\end{array}$ & $\begin{array}{l}4.7948^{\star \star} \\
(1.9673)\end{array}$ & $\begin{array}{l}0.7350^{\star \star \star *} \\
(0.2421)\end{array}$ & $\begin{array}{l}1.6150^{* k \star} \\
(0.2943)\end{array}$ & $\begin{array}{l}1.8652^{2 * \star} \\
(0.2784)\end{array}$ \\
\hline Lag of real GDP growth rate & $\begin{array}{l}0.0004 \\
(0.0010)\end{array}$ & $\begin{array}{l}0.0004 \\
(0.0010)\end{array}$ & $\begin{array}{c}0.0002 \\
(0.0011)\end{array}$ & $\begin{array}{l}0.0068^{*} \\
(0.0038)\end{array}$ & $\begin{array}{c}0.0042 \\
(0.0025)\end{array}$ & $\begin{array}{c}0.0005 \\
(0.0037)\end{array}$ & $\begin{array}{l}0.0030^{* * *} \\
(0.0010)\end{array}$ & $\begin{array}{l}0.0036^{\star \star} \\
(0.0013)\end{array}$ & $\begin{array}{l}0.0037^{* *} \\
(0.0014)\end{array}$ \\
\hline Constant & $\begin{array}{l}0.0227^{\star \star \star} \\
(0.0030)\end{array}$ & $\begin{array}{l}0.0517^{\star \star \star} \\
(0.0049)\end{array}$ & $\begin{array}{c}0.0736^{\star \star \star} \\
(0.0064)\end{array}$ & $\begin{array}{l}-0.0227^{*} \\
(0.0121)\end{array}$ & $\begin{array}{l}-0.0097 \\
(0.0221)\end{array}$ & $\begin{array}{c}0.0516 \\
(0.0390)\end{array}$ & $\begin{array}{c}0.0051 \\
(0.0038)\end{array}$ & $\begin{array}{l}0.0156^{\star \star} \\
(0.0063)\end{array}$ & $\begin{array}{l}0.0264^{\star \star *} \\
(0.0076)\end{array}$ \\
\hline Observations & 147 & 147 & 147 & 147 & 147 & 147 & 147 & 147 & 147 \\
\hline R-squared & 0.8798 & 0.8990 & 0.9042 & 0.7907 & 0.8108 & 0.8201 & 0.7416 & 0.8129 & 0.8289 \\
\hline
\end{tabular}

Source: IMF staff calculations. All regressions control for year and country fixed effects. Clustered robust standard errors in parentheses. ${ }^{*} \mathrm{p}<.10 ; * * \mathrm{p}<.05 ; * * * \mathrm{p}<.01$. 


\begin{tabular}{|c|c|c|c|c|c|c|c|c|c|}
\hline \multicolumn{10}{|c|}{ Table 9. Effects of Macroeconomic Uncertainty using Dummy } \\
\hline \multirow{2}{*}{ Dependent variable } & \multicolumn{3}{|c|}{ Output } & \multicolumn{3}{|c|}{ Private Investment } & \multicolumn{3}{|c|}{ Employment } \\
\hline & $k=0$ & $\mathrm{k}=1$ & $k=2$ & $k=0$ & $\mathrm{k}=1$ & $\mathrm{k}=2$ & $k=0$ & $k=1$ & $\mathrm{k}=2$ \\
\hline High (diff. versus Low) uncertainty: Dummy=1 & $\begin{array}{l}-0.0096 \\
(0.0080)\end{array}$ & $\begin{array}{l}-0.0147 \\
(0.0106)\end{array}$ & $\begin{array}{l}-0.0133 \\
(0.0139)\end{array}$ & $\begin{array}{l}-0.0342 \\
(0.0226)\end{array}$ & $\begin{array}{c}-0.0710^{* * *} \\
(0.0224)\end{array}$ & $\begin{array}{l}-0.0580^{* *} \\
(0.0249)\end{array}$ & $\begin{array}{l}-0.0019 \\
(0.0055)\end{array}$ & $\begin{array}{l}-0.0073 \\
(0.0079)\end{array}$ & $\begin{array}{l}-0.0051 \\
(0.0094)\end{array}$ \\
\hline High uncertainty \# Investment shock & $\begin{array}{l}0.9397^{* *} \\
(0.3906)\end{array}$ & $\begin{array}{c}1.7248^{\star * *} \\
(0.3612)\end{array}$ & $\begin{array}{l}1.6563^{* * *} \\
(0.3530)\end{array}$ & $\begin{array}{c}3.5519^{* * \star} \\
(0.9832)\end{array}$ & $\begin{array}{c}6.6467^{* * *} \\
(1.6991)\end{array}$ & $\begin{array}{l}5.7811^{* *} \\
(2.5628)\end{array}$ & $\begin{array}{c}0.3724 \\
(0.3861)\end{array}$ & $\begin{array}{l}0.8459^{*} \\
(0.4288)\end{array}$ & $\begin{array}{l}1.3662^{* *} \\
(0.5694)\end{array}$ \\
\hline Low uncertainty \# Investment shock & $\begin{array}{c}0.1831 \\
(0.2398)\end{array}$ & $\begin{array}{c}0.1875 \\
(0.4712)\end{array}$ & $\begin{array}{c}0.3949 \\
(0.6987)\end{array}$ & $\begin{array}{c}1.1585 \\
(1.4388)\end{array}$ & $\begin{array}{c}1.5628 \\
(1.8768)\end{array}$ & $\begin{array}{c}0.3289 \\
(2.5952)\end{array}$ & $\begin{array}{c}0.2547 \\
(0.4757)\end{array}$ & $\begin{array}{c}0.5725 \\
(0.6603)\end{array}$ & $\begin{array}{c}1.1779 \\
(0.7486)\end{array}$ \\
\hline Lag of Public investment shock & $\begin{array}{l}0.9083^{* * *} \\
(0.3187)\end{array}$ & $\begin{array}{l}1.2975^{* *} \\
(0.5966)\end{array}$ & $\begin{array}{l}1.4421^{* *} \\
(0.6212)\end{array}$ & $\begin{array}{l}2.7291^{\star \star} \\
(1.1886)\end{array}$ & $\begin{array}{l}5.0132^{* *} \\
(2.3238)\end{array}$ & $\begin{array}{l}5.4632^{* *} \\
(2.3564)\end{array}$ & $\begin{array}{l}0.7806^{* *} \\
(0.2841)\end{array}$ & $\begin{array}{l}1.7577^{\star * *} \\
(0.4636)\end{array}$ & $\begin{array}{c}1.9534^{* * *} \\
(0.5056)\end{array}$ \\
\hline Lag of real GDP growth rate & $\begin{array}{l}-0.0001 \\
(0.0009)\end{array}$ & $\begin{array}{l}-0.0004 \\
(0.0009)\end{array}$ & $\begin{array}{l}-0.0008 \\
(0.0009)\end{array}$ & $\begin{array}{c}0.0048 \\
(0.0028)\end{array}$ & $\begin{array}{c}0.0016 \\
(0.0027)\end{array}$ & $\begin{array}{l}-0.0017 \\
(0.0046)\end{array}$ & $\begin{array}{l}0.0029^{* * *} \\
(0.0010)\end{array}$ & $\begin{array}{l}0.0032^{* * *} \\
(0.0011)\end{array}$ & $\begin{array}{l}0.0032^{* *} \\
(0.0011)\end{array}$ \\
\hline Constant & $\begin{array}{l}0.0082^{* *} \\
(0.0032)\end{array}$ & $\begin{array}{c}0.0258^{* * *} \\
(0.0060)\end{array}$ & $\begin{array}{l}0.0424^{* \star *} \\
(0.0078)\end{array}$ & $\begin{array}{l}-0.0588^{* *} \\
(0.0209)\end{array}$ & $\begin{array}{l}-0.0618^{* *} \\
(0.0269)\end{array}$ & $\begin{array}{l}-0.0336 \\
(0.0300)\end{array}$ & $\begin{array}{c}0.0023 \\
(0.0029)\end{array}$ & $\begin{array}{c}0.0030 \\
(0.0050)\end{array}$ & $\begin{array}{c}0.0046 \\
(0.0067)\end{array}$ \\
\hline Observations & 147 & 147 & 147 & 147 & 147 & 147 & 147 & 147 & 147 \\
\hline R-squared & 0.8294 & 0.8422 & 0.8542 & 0.7354 & 0.7483 & 0.7453 & 0.7338 & 0.7812 & 0.7829 \\
\hline
\end{tabular}

Source: IMF staff calculations. All regressions control for year and country fixed effects. Clustered robust standard errors in parentheses. $* \mathrm{p}<.10 ; * * \mathrm{p}<.05 ; * * * \mathrm{p}<.01$.

\begin{tabular}{|c|c|c|c|c|c|c|c|c|c|}
\hline \multicolumn{10}{|c|}{$\begin{array}{l}\text { Table 10. Effects of Macroeconomic Uncertainty: Interaction with the State of the } \\
\text { Economy as Measured by the Unemployment Rate }\end{array}$} \\
\hline \multirow{2}{*}{ Dependent variable } & \multicolumn{3}{|c|}{ Output } & \multicolumn{3}{|c|}{ Private Investment } & \multicolumn{3}{|c|}{ Employment } \\
\hline & $k=0$ & $k=1$ & $k=2$ & $k=0$ & $k=1$ & $k=2$ & $k=0$ & $k=1$ & $k=2$ \\
\hline High (difference versus Low) unemployment period (Dummy=1) & $\begin{array}{l}-0.0224^{* * *} \\
(0.0062)\end{array}$ & $\begin{array}{c}-0.0322^{* * *} \\
(0.0090)\end{array}$ & $\begin{array}{c}-0.0392^{* * *} \\
(0.0113)\end{array}$ & $\begin{array}{c}-0.0418^{\star \star *} \\
(0.0125)\end{array}$ & $\begin{array}{c}-0.0671^{* * *} \\
(0.0170)\end{array}$ & $\begin{array}{c}-0.0822^{* * *} \\
(0.0257)\end{array}$ & $\begin{array}{l}-0.0054^{*} \\
(0.0029)\end{array}$ & $\begin{array}{l}-0.0150^{*} \\
(0.0074)\end{array}$ & $\begin{array}{c}-0.0225^{* *} \\
(0.0094)\end{array}$ \\
\hline High uncertainty \# Low unemployment rate & $\begin{array}{l}2.5580^{\star *} \\
(0.9456)\end{array}$ & $\begin{array}{l}7.3697^{* * *} \\
(1.7891)\end{array}$ & $\begin{array}{c}9.2249 * * * \\
(3.1788)\end{array}$ & $\begin{array}{c}15.0231^{* * *} \\
(4.6306)\end{array}$ & $\begin{array}{c}29.4946^{* * *} \\
(8.7215)\end{array}$ & $\begin{array}{c}41.3038^{* * *} \\
(12.1715)\end{array}$ & $\begin{array}{l}-1.3585 \\
(0.8305)\end{array}$ & $\begin{array}{l}-0.1536 \\
(1.4411)\end{array}$ & $\begin{array}{r}2.0413 \\
(2.4031)\end{array}$ \\
\hline High uncertainty \# High unemployment & $\begin{array}{l}0.4417 \\
(0.5594)\end{array}$ & $\begin{array}{c}2.2590^{* * *} \\
(0.3215)\end{array}$ & $\begin{array}{c}1.7549 * * * \\
(0.5601)\end{array}$ & $\begin{array}{l}5.9780^{* * *} \\
(1.0034)\end{array}$ & $\begin{array}{c}8.3538^{* * *} \\
(2.1696)\end{array}$ & $\begin{array}{l}4.7921^{\star} \\
(2.5364)\end{array}$ & $\begin{array}{l}0.6825 \\
(0.6129)\end{array}$ & $\begin{array}{l}1.3180^{* *} \\
(0.4927)\end{array}$ & $\begin{array}{c}1.9621^{* * *} \\
(0.2830)\end{array}$ \\
\hline Low uncertainty \# Low unemployment rate & $\begin{array}{l}-1.3173 \\
(0.7753)\end{array}$ & $\begin{array}{c}-4.4158^{* k *} \\
(1.4165)\end{array}$ & $\begin{array}{l}-5.6967{ }^{* \star} \\
(2.6863)\end{array}$ & $\begin{array}{l}-7.8495 \\
(4.6212)\end{array}$ & $\begin{array}{c}-14.6885^{\star \star} \\
(6.2292)\end{array}$ & $\begin{array}{c}-24.4230^{* \star *} \\
(8.2197)\end{array}$ & $\begin{array}{l}1.2511^{\star} \\
(0.6950)\end{array}$ & $\begin{array}{c}0.8283 \\
(1.4375)\end{array}$ & $\begin{array}{l}-0.0077 \\
(1.9247)\end{array}$ \\
\hline Low uncertainty \# High unemployment & $\begin{array}{l}2.3144^{*} \\
(1.2921)\end{array}$ & $\begin{array}{c}1.8708 \\
(1.1172)\end{array}$ & $\begin{array}{l}2.8833^{* *} \\
(1.1287)\end{array}$ & $\begin{array}{c}1.3111 \\
(3.5282)\end{array}$ & $\begin{array}{l}2.1395 \\
(5.6710)\end{array}$ & $\begin{array}{l}5.4240 \\
(5.1780)\end{array}$ & $\begin{array}{l}-0.0416 \\
(1.0343)\end{array}$ & $\begin{array}{l}0.3838 \\
(1.3548)\end{array}$ & $\begin{array}{l}1.2706 \\
(1.4554)\end{array}$ \\
\hline Lag of Public investment shock & $\begin{array}{l}0.7198^{* *} \\
(0.2900)\end{array}$ & $\begin{array}{l}0.9570^{*} \\
(0.4949)\end{array}$ & $\begin{array}{l}1.0157^{* \star} \\
(0.4796)\end{array}$ & $\begin{array}{l}2.0280^{*} \\
(1.0116)\end{array}$ & $\begin{array}{l}3.4730^{*} \\
(2.0004)\end{array}$ & $\begin{array}{l}3.9828^{\star} \\
(1.9761)\end{array}$ & $\begin{array}{l}0.6918^{\star \star} \\
(0.2901)\end{array}$ & $\begin{array}{l}1.4874^{\star \star \star} \\
(0.4088)\end{array}$ & $\begin{array}{l}1.6084^{\star \star *} \\
(0.4067)\end{array}$ \\
\hline Lag of real GDP growth rate & $\begin{array}{l}-0.0021^{* *} \\
(0.0010)\end{array}$ & $\begin{array}{l}-0.0034^{\star \star *} \\
(0.0011)\end{array}$ & $\begin{array}{l}-0.0044^{* * *} \\
(0.0011)\end{array}$ & $\begin{array}{l}0.0008 \\
(0.0030)\end{array}$ & $\begin{array}{l}-0.0065^{*} \\
(0.0032)\end{array}$ & $\begin{array}{l}-0.0115^{* *} \\
(0.0053)\end{array}$ & $\begin{array}{l}0.0023^{* *} \\
(0.0008)\end{array}$ & $\begin{array}{l}0.0017^{\star} \\
(0.0010)\end{array}$ & $\begin{array}{c}0.0010 \\
(0.0010)\end{array}$ \\
\hline Constant & $\begin{array}{l}0.0156^{\star \star \star} \\
(0.0024)\end{array}$ & $\begin{array}{l}0.0378^{\star \star \star} \\
(0.0033)\end{array}$ & $\begin{array}{l}0.0584^{\star \star *} \\
(0.0044)\end{array}$ & $\begin{array}{l}-0.0423^{* *} \\
(0.0200)\end{array}$ & $\begin{array}{l}-0.0323 \\
(0.0303)\end{array}$ & $\begin{array}{c}0.0036 \\
(0.0388)\end{array}$ & $\begin{array}{l}0.0048^{* *} \\
(0.0020)\end{array}$ & $\begin{array}{l}0.0101^{*} \\
(0.0055)\end{array}$ & $\begin{array}{l}0.0159^{* *} \\
(0.0074)\end{array}$ \\
\hline Observations & 147 & 147 & 147 & 147 & 147 & 147 & 147 & 147 & 147 \\
\hline R-squared & 0.8627 & 0.8711 & 0.8822 & 0.7538 & 0.7710 & 0.7725 & 0.7545 & 0.8087 & 0.8126 \\
\hline
\end{tabular}




\begin{tabular}{|c|c|c|c|c|c|c|c|c|c|c|}
\hline \multirow[t]{2}{*}{ Dependent variables } & \multicolumn{2}{|c|}{ Panel A } & \multicolumn{2}{|c|}{ Panel B } & \multicolumn{2}{|c|}{ Panel C } & \multicolumn{2}{|c|}{ Panel D } & \multicolumn{2}{|c|}{ Panel E } \\
\hline & $\mathrm{HU}$ & $\mathrm{LU}$ & $\mathrm{HU}$ & LU & $\mathrm{HU}$ & LU & $\mathrm{HU}$ & $\mathrm{LU}$ & $\mathrm{HU}$ & $\mathrm{LU}$ \\
\hline \multicolumn{11}{|l|}{ Output } \\
\hline$k=0$ & $\begin{array}{c}0.0996 \\
(0.5948)\end{array}$ & $\begin{array}{c}0.7258 \\
(0.9557)\end{array}$ & $\begin{array}{c}0.6175 \\
(0.5132)\end{array}$ & $\begin{array}{c}0.6835 \\
(0.6967)\end{array}$ & $\begin{array}{c}0.7806 \\
(0.9044)\end{array}$ & $\begin{array}{l}-0.6512 \\
(2.0303)\end{array}$ & $\begin{array}{c}0.5782 \\
(0.5275)\end{array}$ & $\begin{array}{c}0.5958 \\
(0.7413)\end{array}$ & $\begin{array}{l}0.6915 \\
(0.4640)\end{array}$ & $\begin{array}{l}0.6324 \\
(0.5971)\end{array}$ \\
\hline$k=1$ & $\begin{array}{l}2.0931^{\star *} \\
(0.9029)\end{array}$ & $\begin{array}{l}-0.4226 \\
(0.8810)\end{array}$ & $\begin{array}{c}2.6436^{\star * \star} \\
(0.7624)\end{array}$ & $\begin{array}{l}-0.2699 \\
(0.8484)\end{array}$ & $\begin{array}{l}3.6642^{* *} \\
(1.4766)\end{array}$ & $\begin{array}{l}-2.5890 \\
(2.5572)\end{array}$ & $\begin{array}{c}2.7451^{\text {** }} \\
(0.8229)\end{array}$ & $\begin{array}{l}-0.3222 \\
(0.8504)\end{array}$ & $\begin{array}{c}2.5632^{\star \star \star} \\
(0.7083)\end{array}$ & $\begin{array}{l}-0.0782 \\
(0.7139)\end{array}$ \\
\hline$k=2$ & $\begin{array}{c}1.4860 \\
(0.9096)\end{array}$ & $\begin{array}{c}0.2398 \\
(0.9528)\end{array}$ & $\begin{array}{c}2.3137^{\star \star *} \\
(0.6437)\end{array}$ & $\left.\begin{array}{c}1.9147^{\star} \\
(0.9810)\end{array}\right]$ & $\begin{array}{l}3.1745^{*} \\
(1.2706)\end{array}$ & $\begin{array}{l}-2.0240 \\
(3.8420)\end{array}$ & $\begin{array}{c}2.5258^{\star \star *} \\
(0.6191)\end{array}$ & $\begin{array}{c}0.1186 \\
(0.9990)\end{array}$ & $\begin{array}{c}2.3394^{\star \star \star} \\
(0.5871)\end{array}$ & $\begin{array}{l}0.1878 \\
(0.9011)\end{array}$ \\
\hline \multicolumn{11}{|l|}{ Private Investment } \\
\hline$k=0$ & $\begin{array}{l}6.7248^{* \star *} \\
(2.2162)\end{array}$ & $\begin{array}{l}-4.2983^{*} \\
(2.0851)\end{array}$ & $\begin{array}{l}6.6584^{\star \star *} \\
(1.5433)\end{array}$ & $\begin{array}{l}-1.3671 \\
(2.7628)\end{array}$ & $\begin{array}{l}6.0464^{* \star} \\
(2.5585)\end{array}$ & $\begin{array}{l}-2.9444 \\
(4.8340)\end{array}$ & $\begin{array}{l}6.6050^{\star \star \star} \\
(1.8128)\end{array}$ & $\begin{array}{l}-1.3311 \\
(2.8380)\end{array}$ & $\begin{array}{l}6.2295^{\star \star \star} \\
(1.3541)\end{array}$ & $\begin{array}{l}-0.3743 \\
(2.3726)\end{array}$ \\
\hline$k=1$ & $10.6270^{* *}$ & $\begin{array}{l}-3.8949 \\
1272099\end{array}$ & $10.0391^{1 * *}$ & -0.0713 & $7.1319^{*}$ & -6.1944 & $10.1326^{* * *}$ & $\begin{array}{l}-0.1535 \\
(1.2261)\end{array}$ & $9.1101^{* \star *}$ & 1.0684 \\
\hline \multirow[t]{2}{*}{$k=2$} & $\begin{array}{l}(4.3037) \\
8.4824^{\star}\end{array}$ & $\begin{array}{l}(3.2398) \\
-4.8553\end{array}$ & $\begin{array}{l}(2.2570) \\
7.6912^{* \star}\end{array}$ & $\begin{array}{l}(4.2462) \\
-0.1978\end{array} \mid$ & $\begin{array}{c}(3.5774) \\
3.7738\end{array}$ & $\begin{array}{l}(8.2691) \\
-2.8957\end{array}$ & $\begin{array}{l}(2.2996) \\
8.1470^{\star \star \star}\end{array}$ & $\begin{array}{c}(4.3264) \\
0.1734\end{array}$ & $\begin{array}{l}(2.2303) \\
7.2970^{\star \star}\end{array}$ & $\begin{array}{l}(3.8346) \\
0.6705\end{array}$ \\
\hline & $(4.5695)$ & (4.6699) & $(3.1729)$ & (5.5819) & (5.5044) & (15.6194) & (2.7099) & $(5.3792)$ & $(3.0131)$ & (4.9118) \\
\hline \multicolumn{11}{|l|}{ Employment } \\
\hline$k=0$ & $\begin{array}{c}0.1793 \\
(0.4101)\end{array}$ & $\begin{array}{l}0.6641^{\star \star} \\
(0.2500)\end{array}$ & $\begin{array}{c}0.5262 \\
(0.3902)\end{array}$ & $\begin{array}{c}0.2982 \\
(0.6787)\end{array}$ & $\begin{array}{c}0.6458 \\
(0.5117)\end{array}$ & $\begin{array}{l}-0.6483 \\
(1.2628)\end{array}$ & $\begin{array}{l}0.4635 \\
(0.4049)\end{array}$ & $\begin{array}{c}0.1150 \\
(0.7138)\end{array}$ & $\begin{array}{l}0.5228 \\
(0.3758)\end{array}$ & $\begin{array}{l}0.1647 \\
(0.6592)\end{array}$ \\
\hline$k=1$ & $\begin{array}{l}0.9010^{\star *} \\
(0.3414)\end{array}$ & $\begin{array}{r}1.1124^{\star \star \star} \\
(0.3761)\end{array}$ & $\begin{array}{l}1.1051^{* \star *} \\
(0.1939)\end{array}$ & $\begin{array}{c}0.3872 \\
(1.0386)\end{array}$ & $\begin{array}{c}1.6240^{* * *} \\
(0.5213)\end{array}$ & $\begin{array}{l}-1.1904 \\
(2.0490)\end{array}$ & $\begin{array}{l}1.1459^{* \star *} \\
(0.2479)\end{array}$ & $\begin{array}{c}0.2979 \\
(1.0145)\end{array}$ & $\begin{array}{l}1.1687^{* \star *} \\
(0.2006)\end{array}$ & $\begin{array}{l}0.4007 \\
(0.9141)\end{array}$ \\
\hline$k=2$ & $\begin{array}{l}1.3265^{\star} \\
(0.7564)\end{array}$ & $\begin{array}{l}1.2255^{\star \star} \\
(0.4775)\end{array}$ & $\begin{array}{l}1.9079 * * \star \\
(0.3293)\end{array}$ & $\begin{array}{c}0.7021 \\
(1.2926)\end{array}$ & $\begin{array}{r}2.2965^{\star \star \star} \\
(0.7186)\end{array}$ & $\begin{array}{l}-0.9707 \\
(2.8971)\end{array}$ & $\begin{array}{l}1.9730^{* \star *} \\
(0.3362)\end{array}$ & $\begin{array}{c}0.6729 \\
(1.2810)\end{array}$ & $\begin{array}{c}1.9048^{\star \star \star} \\
(0.3255)\end{array}$ & $\begin{array}{l}0.7882 \\
(1.1358)\end{array}$ \\
\hline $\begin{array}{l}\text { Source: IMF staff c } \\
\text { Notes: } 1 / \text { The table } \\
\text { (LU). } 2 / \text { Panel A us } \\
\text { shocks. The sample } \\
\mathrm{D} \text {, the estimation cc } \\
\text { is equal to } 1.5 \text { as in } \\
\text { effects. Clustered r }\end{array}$ & $\begin{array}{l}\text { lations. } \\
\text { ents the } \\
\text { e differer } \\
\text { esctricted } \\
\text { ls for the } \\
\text { erbach an } \\
\text { t standarc }\end{array}$ & $\begin{array}{l}\text { nce betw } \\
\text { d to adval } \\
\text { e output } \\
\text { d Gorodi } \\
d \text { errors i }\end{array}$ & $\begin{array}{l}\text { ced econor } \\
\text { p. Panel } \mathrm{E} \\
\text { chenko (2 } \\
\text { parenthes }\end{array}$ & $\begin{array}{l}\text { lized inv } \\
\text { mies in I } \\
\text { E shows } \\
\text { 2013a). } 3 \\
\text { ses. }{ }^{*} p<\end{array}$ & $\begin{array}{l}\text { estment } \\
\text { Panel B, } \\
\text { the resu } \\
\text { /All reg } \\
10 . * *\end{array}$ & $\begin{array}{l}\text { when } \\
\text { sions } \\
.05 ;\end{array}$ & $\begin{array}{l}\text { ig forecas } \\
2007-20 \\
\text { curvature } \\
\text { rol for ye } \\
<.01 \text {. }\end{array}$ & $\begin{array}{l}\text { st vintag } \\
019 \text { for } P \\
e \text { of the ti } \\
\text { ear and } c\end{array}$ & $\begin{array}{l}\text { as invest } \\
\text { ansition } \mathrm{C} \\
\text { ountry fix }\end{array}$ & $\begin{array}{l}\text { ertainty } \\
\text { tment } \\
\text { panel } \\
\text { function } \\
\text { ed }\end{array}$ \\
\hline
\end{tabular}

